\title{
THE ASIAN AND EUROPEAN BANKING SYSTEMS: THE CASE OF SPAIN IN THE QUEST FOR DEVELOPMENT AND ESTABILITY
}

Sonsoles Gallego, Alicia García Herrero and Jesús Saurina

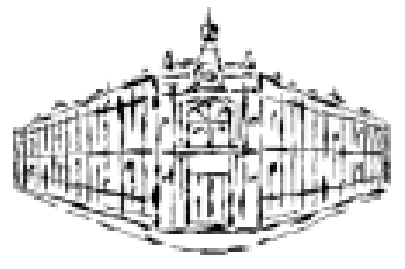

Banco de España - Servicio de Estudios Documento de Trabajo n. $^{\circ} 0217$ 


\title{
The Asian and European Banking Systems: \\ The case of Spain in the quest for development and stability
}

\author{
Sonsoles Gallego, Alicia García Herrero and Jesús Saurina ${ }^{1}$
}

July, 2002

\begin{abstract}
After a brief review of the literature on the determinants of financial development, the paper reviews the Asian and European financial systems in terms of their size and efficiency. It also compares the steps taken in the two regions in the quest for financial development and stability, which in a few cases are very similar but differ markedly in others. While there has been a clear move towards a more balanced financial structure in both regions, financial liberalization, as well as the strengthening of bank regulation and supervision occurred later in Asia and with a different speed and sequencing. The most striking difference between the two areas is the degree of international - and regional - financial integration, much lower for Asia. Finally, the case of Spain as a European country with a finance-led convergence process - is analyzed in more detail. Lessons are drawn from the Spanish experience for Asian countries.
\end{abstract}

JEL Classification Numbers: G10, G 20

Key words: Financial development, financial liberalization, Spanish financial system

\footnotetext{
1 This article was prepared in the framework of the KOBE research project, which gathered research on Asian and European financial systems and regional economic and financial integration. All authors are from Banco de España. The opinions expressed are those of the authors and do not necessarily reflect the views of Banco de España. We thank Lucia Cuadro for her excellent data handling. We gratefully acknowledge comments from Srini Madhur, Carlos Perez de Eulate, Teresa Sastre, and Jorge Martinez Pagés on an earlier version of the paper. All remaining errors are our own. Corresponding address: alicia.garcia-herrero@bde.es
} 


\section{TABLE OF CONTENTS}

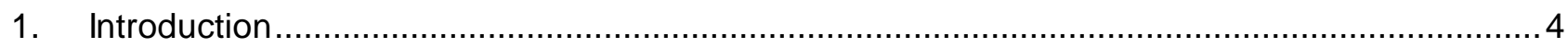

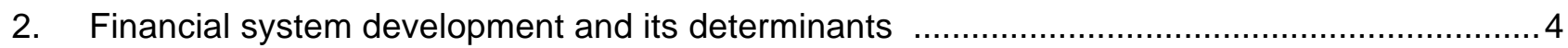

2.1 Financial structure: bank versus capital markets financing .......................................... 6

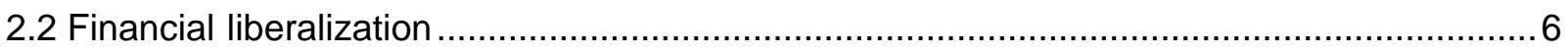

2.3 Banking crises and the improvement of bank supervision and deposit insurance schemes 7

2.4 International (or regional) financial integration ...........................................................

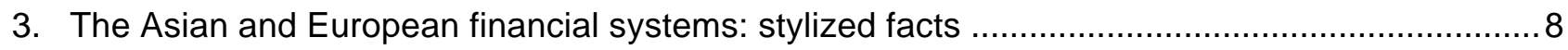

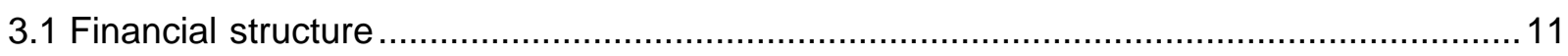

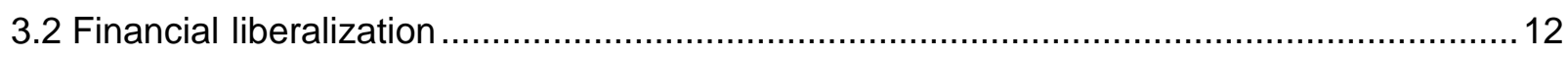

3.3 Banking crises, the improvement in bank regulation and supervision and the DIS ........... 18

3.4 International - and regional- financial Integration ....................................................... 19

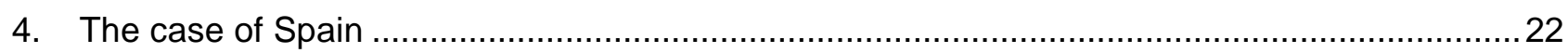

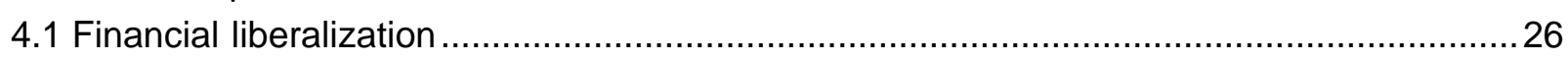

4.2 The banking crisis and the improvement of regulation and supervision ...........................28

4.3 The change in the bank structure: Commercial banks versus savings banks ................... 31

4.4 The process towards international and regional integration ..........................................32

5. Conclusions and possible lessons from the Spanish experience for Asian countries ................35

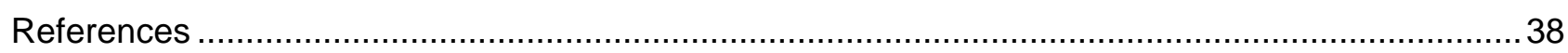




\section{GRAPHS}

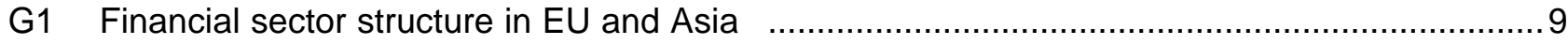

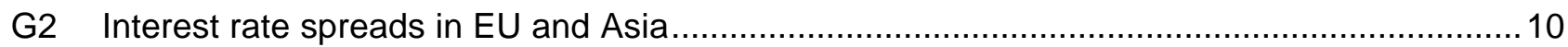

G3 Stock market turnover ratio in EU and Asia ............................................................ 11

G4 Credit to the private sector in the Euro Area and Asia ................................................ 13

G5 Germany: financial liberalization, banking crises and financial depth .................................. 14

G6 France: financial liberalization, banking crises and financial depth.................................... 14

G7 UK: financial liberalization, banking crises and financial depth ..................................... 14

G8 Italy: financial liberalization, banking crises and financial depth....................................... 15

G9 Indonesia: financial liberalization, banking crises and financial depth .............................16

G10 Thailand: financial liberalization, banking crises and financial depth ..................................16

G11 South Korea: financial liberalization, banking crises and financial depth.............................16

G12 Malaysia: financial liberalization, banking crises and financial depth ................................. 17

G13 The Philippines: financial liberalization, banking crises and financial depth .......................17

G14 Foreign bank participation in selected European and Asian countries...............................19

G15 Consolidated international bank claims by selected European countries ............................21

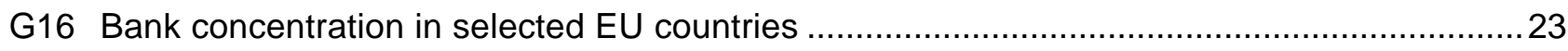

G17 Operating income as a percentage of total assets in EU countries....................................24

G18 Operating costs to operating income in selected EU countries .........................................24

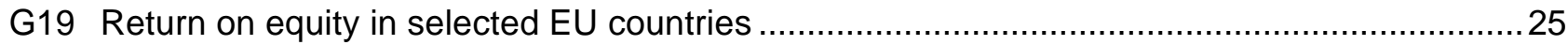

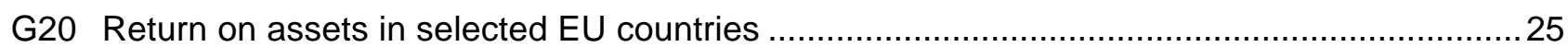

G21 Financial liberalization, the banking crisis and financial depth in Spain .............................2 27

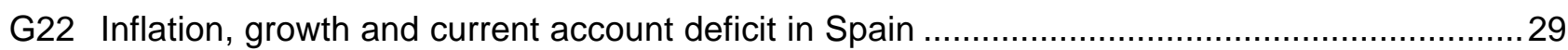

G23 Distribution of total foreign assets of the Spanish banking system in Latin America.............34

\section{TABLES}

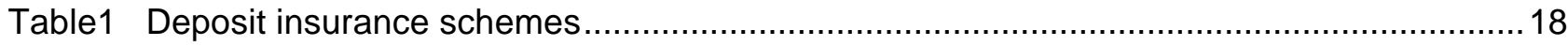

Table 2 Deregulation and financial market changes in the Spanish banking system ...................28 


\section{Introduction}

Recent research has illustrated how financial systems have contributed to economic development, by increasing total factor productivity and ultimately economic growth. Aware of the important role that finance plays for growth, both Asia and Europe have striven to develop their financial systems while trying to maintain financial stability. Some of the steps taken are similar in both regions, including the evolution towards a more balanced financial structure from a bank-based one, financial liberalization, although with a different timing and speed, and the ensuing strengthening of financial supervision following crisis events. Other steps are, however, very different, especially what concerns the degree of international, and especially, regional integration

Taking as a benchmark a brief review of the experience in both regions, the paper deals with the case of Spain as a country whose process of economic convergence to EU levels has been based, among other factors, on financial development. In fact, the Spanish banking system experienced a deep but lengthy liberalization process, which increased the efficiency of the whole economy. However, a significant banking crisis occurred a few years after the liberalization process started, although liberalization was not the main reason. Building up from this painful experience, the regulatory framework was improved and solvency monitoring arose as the main driving force for banking supervisors. As a result of this, among other factors such as EU entry and the opening to global competition, the Spanish banking system is now very sound and competitive for European standards, and has managed to expand overseas at large scale, particularly in Latin America. The banking system remains, therefore, one of the main driving forces of convergence.

The paper is divided into four major sections. Section 1 briefly describes the general consensus found in the literature regarding the characteristics of the financial sector which better foster its development and, ultimately, economic growth, as well as the role of financial liberalization, bank supervision and international and regional integration. Section 2 provides some stylized facts comparing financial size and structure, financial liberalization, bank supervision and international and regional integration in Asia and Europe. Section 4 delves into the Spanish positive and negative experiences with financial development. Conclusions are drawn in Section 5.

\section{Financial system development and its determinants}

Recent research broadly agrees that financial development contributes to economic growth ${ }^{2}$. The so-called "finance-led" economic literature on growth argues that financial development increases total factor productivity and ultimately economic growth through the functions inherent to the financial system, namely mobilizing savings, allocating capital, monitoring managers and transforming risk. In addition, even in a world of perfect capital mobility, savings and investment do not equalize, which makes domestic financial development very relevant for economic growth.

\footnotetext{
2 The debate on the role of financial systems on growth is well-rooted in the history of economic thought. Already Bagehot (1873) and Schumpeter (1911) attributed a key role for economic development to a country's banking system. The recent interest in the role of the financial system on growth is related to the developments of the new growth theory. While innovation and knowledge creation are the main forces behind capital accumulation and growth in this literature, financial intermediaries also plays a role to the extent that innovation and knowledge are financed with external funds (Levine, 1991; King and Levine, 1992; and Chen et al., 1996)
} 
Empirical financial literature is plentiful of success cases of financial development ${ }^{3}$, but also of less positive experiences. The main general conclusion that one can draw from this literature is that there is no single success model although useful lessons can be drawn from other countries positive experiences and mistakes.

Before analyzing the factors that affect financial development, one should note that financial development may be defined in several ways. In fact, financial systems can develop in terms of size but also in terms of the efficiency in which they intermediate funds. One might be tempted to think that "big is always better" for the financial system but this is not necessarily the case in all countries. For example a banking system in distress may be big in terms of assets while a large share may be unproductive or non-performing credit and, thus, does not contribute to growth. The same banking system after a crisis will become smaller, either because of deposit runs, the clean up of non-performing loans or bank closures, but will probably be able to intermediate funds more efficiently, especially if the crisis is tackled correctly.

Financial development in terms of size is generally called financial depth. Narrow definitions of financial depth include bank liquid liabilities to GDP (or M2) or bank credit to the private sector to GDP. Wider measures of financial depth include the domestic capital markets as well as the banking system ${ }^{4}$.

Financial efficiency is hard to measure for the financial system as a whole. The literature has developed measures of efficiency for the different markets that compose the financial system. For the banking sector, the most widely used measure is the net interest margin together with the spread between the lending and the deposit rate. When the net interest margin, or the spread, is narrow, it tends to be associated with greater competition although there may be other reasons, such as low interest rates, particularly in developed countries, and macroeconomic volatility in emerging countries. As regards the capital markets, the most readably available measure of efficiency is turnover, which gives the value of stock transactions relative to the size of the financial market.

Turning to the factors that foster financial development, the literature concentrated first on macroeconomic factors, such as inflation ${ }^{5}$ and how wealthy countries are in terms of GDP per

\footnotetext{
${ }^{3}$ Rousseau and Sylla (2001) carry out a historical review of the Dutch Republic, England, the U.S., France, Germany and Japan and show how in each case the emergence of a financial system jump-started economic growth. Allen and Gale (2000) provide a comprehensive analysis for a similar group of countries. Caprio, Hanson and Honohan (2001) review the benefits and pitfalls of financial liberalization in emerging markets.

${ }^{4}$ Although broad, the latter still misses important sources of financing, such as enterprise financing, external financing (through interbank loans or bonds) and the informal financial sector.

${ }^{5}$ Boyd, Levine and Smith (2000) find empirical evidence that at low-to-moderate rates of inflation, increases in inflation hamper financial development, in terms of lower volumes of bank lending to the private sector. Khan et al. (2001) basically find the same result with the addition that there is a floor for inflation, below which financial development is hampered as well. More specifically, they find that under certain conditions inflation below $3 \%$ and above $6 \%$ is detrimental for the main definitions of financial depth (from bank credit to broader ones including stock market capitalization).
} 
capita as well as the saving rate ${ }^{6}$. More recently, it has attached a lot of importance to institutional factors, such as the legal and regulatory system ${ }^{7}$, as well as the structure and functioning of the financial system itself. This paper will concentrate in some of the latter factors ${ }^{8}$.

\subsection{Financial structure: bank versus capital markets financing}

The long-standing debate as to whether bank financing or capital market financing is better for economic growth appears to have reached consensus with recent research. La Porta, Lopez-de Silanes, Shleifer and Vishny (1997), Levine (1998 and 1999) and Barth, Caprio and Levine (2000) show evidence that the choice between a bank-based and a capital-market based structure is not key for financial development but rather the institutional factors behind the financial structure, and in particular the legal environment, as well as how efficient and safe financial systems are, as shall be touched upon later. Allen and Gale (2000) reach similar conclusions after describing the tradeoffs of both models, arguing that the appropriate choice must be made on an ad-hoc basis depending on issues such as the importance attributed to the redistribution of risk and funding of new industries. All this, however, does not mean that the financial structure is irrelevant. In fact, it appears that most success cases of financial development have a relatively balanced mixture of capital markets and bank financing (Davis, 2001) since bank and capital market financing tend to complement rather than substitute each other.

\subsection{Financial liberalization}

While the economic literature agrees that financial liberalization strongly contributes to the development of the financial sector in the long run (Shaw, 1973; McKinnon, 1991; and Bailliu, 2000), the evidence is much more mixed for the transition period, especially as regards external financial liberalization and particularly that of the capital account. On the one hand, capital account liberalization offers the opportunity of receiving more funds to develop domestic financial markets, especially when control on foreign ownership of banks is relaxed (IMF, 2000). On the other hand, it carries risks of financial instability if the appropriate institutional framework is not in place when liberalizing (Williamson and Mahar 1998). Such risks stem from the increased competition, which erodes financial firms' margins in a new environment. In those circumstances, and in the absence of strict supervision and internal risk control systems, financial firms increase their risk exposure through unconstrained lending activities. This risk of financial instability has been the main reason for a good part of the economic literature to advocate gradual - and well-sequenced - liberalization processes with a strengthening of the overall policy environment alongside (Caprio et al. 1999). As regards the sequencing, the general view is that macroeconomic stability should take place first, followed by domestic financial liberalization and leave capita account liberalization as the last step (McKinnon, 1991). Nonetheless, based on political economy considerations, Johnston (1998) emphasizes that early capital account liberalization can have an important catalytic role in promoting broader economic reforms.

\footnotetext{
${ }^{6}$ Jaffee and Levonian (2000) find that both GDP per capita and savings are significant to explain financial development.

${ }^{7}$ Levine, Loayza and Beck (1999) find that countries with legal and regulatory systems that give a high priority to creditors have better functioning financial intermediaries.

${ }^{8}$ For a broader review of the financial-sytem related factors which foster financial development see García Herrero et al. (2002).
} 
Regarding stock market liberalization, the opening of the equity market to international investors constitutes a crucial point towards its development, with large consequences on the level and dynamics of asset pricing as Bekaert et al. (2000) show.

\subsection{Banking crises and the improvement of bank supervision and deposit insurance schemes}

Banking crises are obviously detrimental for financial development in the short run, since all who depend on financial services suffer, but under certain circumstances their impact may be positive in the long run if they are tackled properly. In fact, a crisis might sometimes be the only way for a banking system to be cleaned up properly and for bank credit to resume. On the contrary, if banks continued to be saddled with non-performing loans, the country may not manage to develop financially even in the long term.

One indirect beneficial consequence of banking crises has often been the subsequent improvement in the quality of bank regulation and supervision as a reaction to the crisis. The literature has long argued that high quality regulation and supervision fosters financial development. Although it is not always easy to determine what is meant by high quality supervision $^{9}$, there is broad consensus on the importance of solvency as driving force of financial regulation, and the independence on supervisors from the political sphere. In this regard, a recent survey conducted by the World Bank (Barth et al. 2001) with information on the quality of bank regulation and supervision for virtually all countries in the world has been the basis of several empirical studies, which widely support this view. In particular, Demirguc-Kunt and Levine (1999) find that countries with regulations that overly restrict the rights of banks to engage in securities market activities, real state and insurance are more likely to have underdeveloped financial systems

As regards deposit insurance schemes (DIS), they appear to foster financial development as long as the DIS is explicit and limited (Dale et al. 2000), and the institutional environment, particularly the regulatory system is sound (Cull et al., 2000). However, if implicit or unlimited, the DIS may increase the probability of banking crises (Demirguc-Kunt and Detragiache, 1998). Demirgüc-Kunt and Kane, 2001 also argue that banks membership to the DIS should be compulsory and the funds should rather be jointly managed by the public and the private sector.

\subsection{International (and regional) financial integration}

There is broad consensus in the literature that international (or regional) financial integration fosters financial development, particularly for small countries. How much a country will benefit from international (or regional) financial integration will very much depend on the nature of such integration, especially how stable and secure it is. We consider three dimensions of it:

\footnotetext{
${ }^{9}$ There are many ways in which financial regulation and supervision is conducted around the world. Some countries tend to be more structure oriented, with functional separation of institutions, and others more conduct oriented, focusing on disclosure and pricing rules (Vives 1990).
} 
The first one is opening up the domestic banking system to foreign competition by allowing foreign presence. Several reasons have been given for its positive impact, among which: foreign entry brings fresh capital into the banking system, which can be intermediated and thus increase the size of the domestic financial system (Kroszner 1998). It also limits the volatility of capital movements and financial markets in general (Kono and Schuknecht,1999) given that foreign banks start to lend domestically. Finally, management and expertise is imported, which should foster efficiency and competition, improve internal risk management and increase solvency in terms of higher loan-loss provisioning (Claessens et al., 2000 and Crystal et al., 2001).

The second is exporting or importing funds -depending on the financing needs at home. This is very much related to external financial liberalization since it is the way to open the door to private external financing or to investing abroad. One of the main advantages of opening up to exporting or importing funds is that it allows for a better allocation of capital and reduces the cost of financing for capital importers. An interesting question is whether the access to external financing acts as a substitute of domestic financing, thereby hampering the country's financial development, or rather as complement. The literature broadly supports the latter. Jaffee and Levonian (2000) find for a large group of countries that opening the countries to external financing fosters financial development ${ }^{10}$. As regards the exporting of funds, what we shall call outward internationalization, it has become more and more important for mature banking systems, as a way to better diversify risk and achieve a higher return.

The third aspect is regional integration of markets as well as their infrastructure. Regional market integration generally reduces concerted pricing and collusive agreements by increasing competition in a larger economic area. This is particularly important for the financial development of small countries because of the potential efficiency gains from economies of scale and scope ${ }^{11}$ but not only, as the European case shows ${ }^{12}$. Technological development has enormously increased efficiency gains of very large markets, which explains why also relatively large countries can benefit from close regional integration. The same is true for the infrastructure of financial markets, such as trading, clearing and settlement systems, which generally need a large investment to keep them up to date and are subject to large economies of scale. Sharing financial infrastructure with other countries in a region, or simply importing key infrastructure from a more developed country, allows financial modernization with a lower cost and should facilitate the entry of foreign investment. The European experience has been very successful as regards the payments system while progress is still underway in the field of securities.

\section{The Asian and European financial systems: stylized facts}

While European and much more so Asian countries are rather heterogeneous, a brief comparison of the degree of financial development in the two regions will now be conducted. The group of

\footnotetext{
${ }^{10}$ The measure of external financing used is the ratio of non-resident claims to total claims on banks.

${ }^{11}$ Berger (2000) finds empirical evidence of the large potential for efficiency gains from integration although only a small part of these gains are generally realized. Most of the gains appear to be linked to the benefits of risk diversification.

12 Giovanni and Mayer (1990) show evidence of the high costs of financial market segmentation in Europe and the substantial benefits of regional integration.
} 
countries selected to calculate the averages for the European and Asian regions are the $15 \mathrm{EU}$ countries, and China, Indonesia, Malaysia, Philippines, South Korea, Thailand, Hong Kong and Singapore for Asia, unless indicated otherwise ${ }^{13}$.

Differences in financial depth, measured broadly by the sum of bank liquid liabilities, stock market capitalization and bond market outstanding, between Asia and Europe have shrunk over time. Financial depth was very low in the 1970s in Asia, below 25\% of GDP on average and exclusively concentrated in the banking system. The European financial systems were twice as large, with bank liquid liabilities of $50 \%$ of GDP on average. Financial systems grew mildly through the 1980 s in both regions, but growth picked up sharply in the first half of the 1990s, particularly in Asia, due in part to financial liberalization, and also to the beginning of several privatization processes ${ }^{14}$. Europe completed its liberalization at the beginning of the 1990s, while Asia liberalized in general some time later. By 1996, one year before the Asian crisis hit, the average size of the financial sectors in Asia had overtaken those in Europe, reaching levels well above 250\% of GDP.

G1 Financial sector structure in EU and Asia (\% share of GDP)

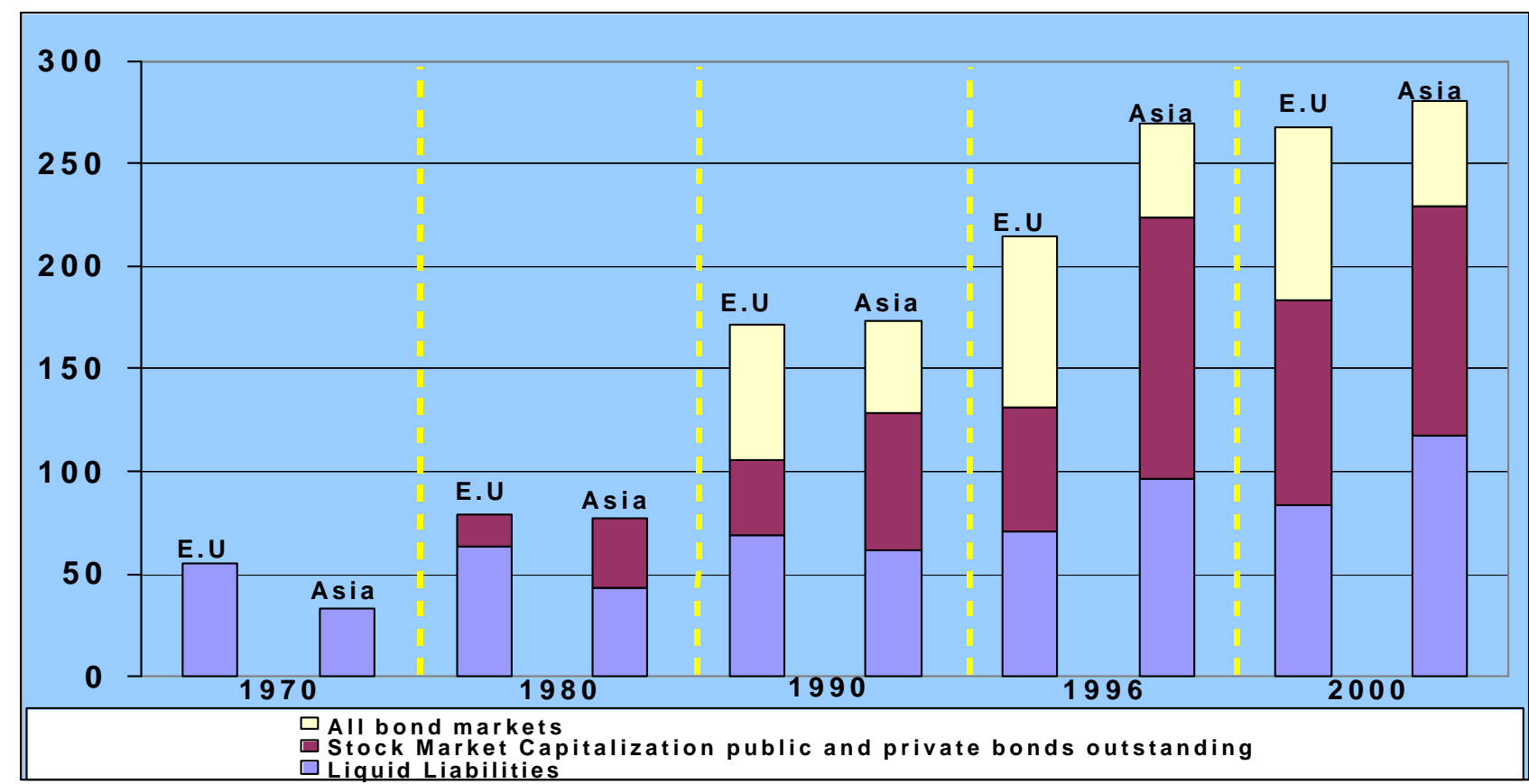

Source: IFS 2001, Beck 1999, BIS 2000, Bloomberg

Note: Data for bond outstanding in 1980s, and for stock market and bond outstanding in 1970s are not available in this Dataset, so the graph may be underestimating financial depth in both decades.

This average to some extent overestimates the situation in the region, being influenced by the very high ratios of stock market capitalization to GDP of three countries (Hong Kong, Singapore and Malaysia). The Asian financial crisis brought a sharp reduction in size across most financial systems in the region, affecting banks but especially the capital markets. However, figures for the

\footnotetext{
${ }^{13}$ Note that averages are unweighted as some of them are ratios and, in general, we are trying to show general regional trends and not the weightings of different countries in those regions.

${ }^{14}$ Privatization is still partial in Europe. The European model is not one of full privatization, but one in which privatelyowned and government-owned banks coexist.
} 
year 2000 show that the Asian crisis moderated financial depth, but did not cause a lasting trend reversal. ${ }^{15}$

As regards financial efficiency the banking system and the capital markets will be analyzed separately due to the lack of global indicators of efficiency. Regarding bank efficiency, the net interest margin has shown improvements in Europe, from an average of $2 \%$ in the period 1992-97 and even higher level in the 1980s (2.3\% on average) it reached $1.5 \%$ in 1999 (ECB, 1999). In Asia, the net interest revenue also fell from 2.6\% in the period 1992-97 to 2.2\% in 1999 (Hawkins and Mihaljek, 2001) but the two measures are not easily comparable. The evolution of the spread between the lending and the deposit interest rates has not been very positive for efficiency in any of the two regions: while it has continued to increase in Asia, it has fallen in Europe but still stands at relatively high levels. As regards the stock market efficiency, measured by its turnover, it fell in Asia as a result of the crisis, but it is still slightly higher than that of Europe.

G2 Interest rate spreads in EU and Asia (in percentage points)

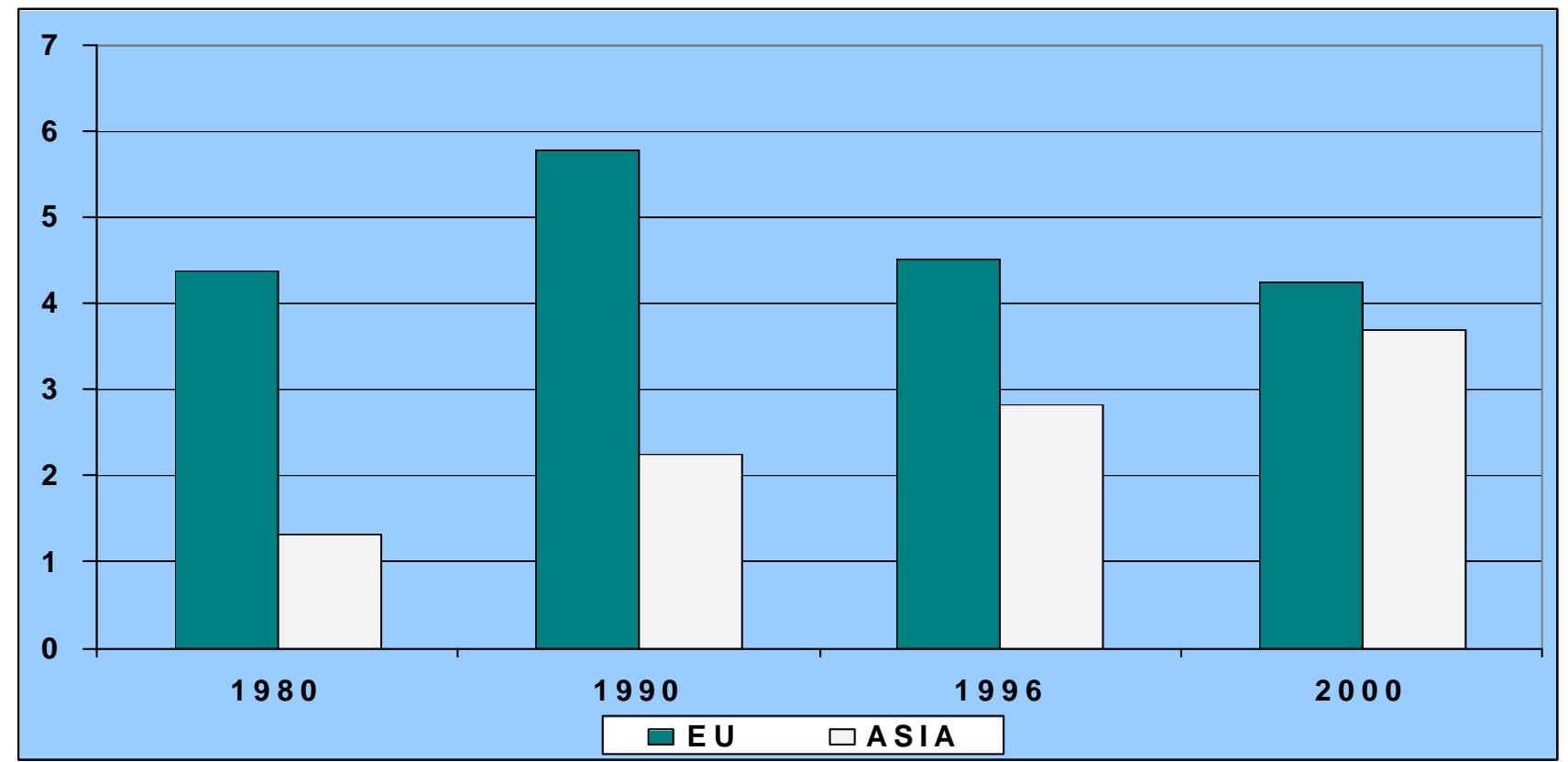

Source: IFS 2001

In sum, financial systems have continued to develop and grow in size both in Asia and Europe until today. Efficiency has increased in Europe both in the banking system and the stock market but there is still room for further improvement. Asia relatively high level of efficiency, both in the banking system and the stock market, has lost ground particularly after the 1997 crisis.

As regards the structure and functioning of the banking system, there are similarities and differences between Asia and Europe. The total number of credit institutions is similar, about

\footnotetext{
${ }^{15}$ Two important caveats apply to these conclusions. On the one hand, the analysis is constrained by the fact that the heterogeneity of financial system sizes in Asia is significantly greater than in Europe, as shows standard deviations almost four times larger for Asia. However, even accounting for this fact, conclusions are quite robust: if we take out of the sample Hong Kong and Singapore, the average size of the financial system continues to be larger in Asia than in Europe in 1996 (215\% of GDP) and only moderately lower in 2000 (196\% of GDP).
} 
10,000 on average, which compares with the US and is much higher than Latin America and Eastern Europe ${ }^{16}$. Bank concentration has remained higher in Europe than in Asia, with about 55\%

G3 Stock market turnover ratio in EU and Asia (as a share of GDP)

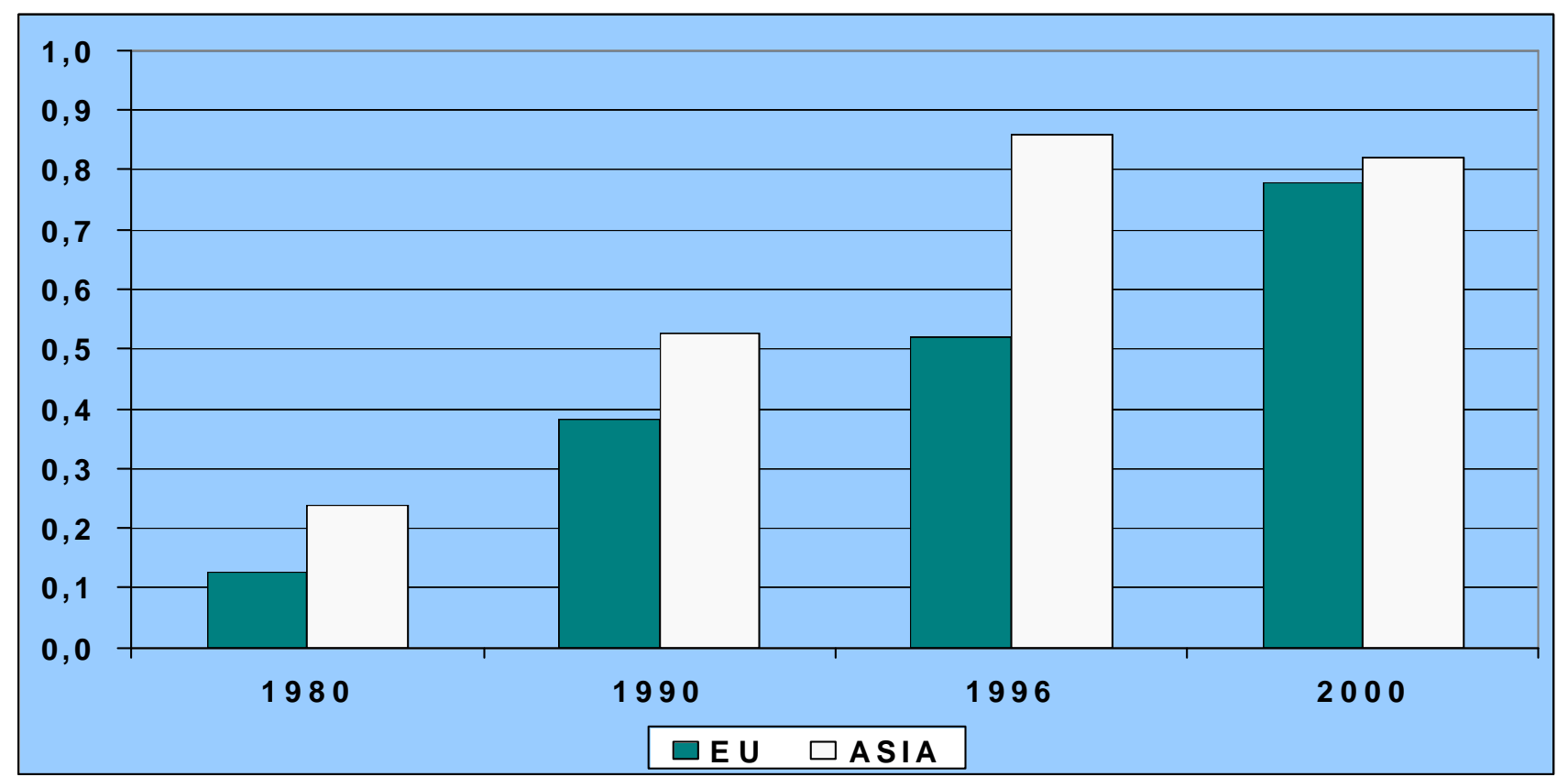

Source: Bloomberg

of total deposits in the hands of the five largest banks compared to $43 \%$ in Asia ${ }^{17}$. Profitability is also higher in Europe, particularly after the Asian crisis, with returns on assets at about 0.8 on average, compared to $-1.2 \%$ for Asia. Solvency ratios are similar; the average risk-weighted capital ratio in Asia reached $11.9 \%$ in $1999^{18}$ compared to $11.5 \%$ in Europe, although risk measures are probably not easily comparable.

\subsection{Financial structure}

As shown in the above graphs of financial depth, both Asian and European financial systems have traditionally been predominantly bank-based, and not market-based. Such differentiation began to blur, first with the expansion of domestic bond markets in the second half of the 1980, particularly in Europe and, second, with the stock market boom of the early 1990s. By 1996, the size of stock markets in Asia had surpassed the total amount of bank liquid liabilities in the system. The subsequent adjustment in Asia during the crisis reduced the size of the stock market relative to GDP, although not sharply, and increased the share of bank liquid liabilities. Europe's stock market boomed later, in the second half of the 1990s, and has also suffered a sharp correction just recently.

\footnotetext{
${ }^{16}$ For a comparison of the Asian financial system with that of Latin America and Eastern Europe, see García Herrero et al. (2002)

171999 data in the case of Asia (Hawkins and Mihaljek, 2001) and 1997 data for Europe (ECB, 1999). The 15 Member States are included in the European average while the selected Asian countries are Korea, Malaysia, the Philippines and Thailand.

${ }^{18}$ Indonesia is excluded due to the still highly negative risk-weighted capital ratio in 1999.
} 
All in all, the structure of the financial system is rather balanced in both regions, as favored in the economic literature. This does not mean, however, that the banking system has lost its prominence. The larger volatility of capital markets, particularly for Asia, and the involvement of the banking system in the capital markets in many European countries with universal banking but also in some Asian ones ${ }^{19}$, retains the crucial role of the banking system in the financial development of both regions.

\subsection{Financial liberalization}

Both Asia and Europe have pursued financial liberalization as a means to enhance competition and efficiency in their financial systems, and broaden the provision of financial services. Liberalization processes in the two regions hold similarities but also crucial differences which play a role in explaining the present shape of financial systems, as well as the incidence of crises. The main differences refer to the starting point and length of the liberalization processes, but also to how the liberalization of the different sectors was sequenced (banking, capital markets and external flows, particularly the capital account). While in Europe financial liberalization started in the mid 1970s, it did not gather speed until the mid 1980s. In Asia liberalization processes start later and suffered from more reversals and -as a consequence - it took longer to complete them.

A few conclusions can be drawn from the graphs in this section showing bank liquid liabilities and credit to the private sector, both as a percentage of GDP, for a selected group of Asian and European countries, together with three measures of the degree of financial liberalization over time, one for the domestic financial sector, another for the capital account, and the last for the stock market. These measures have been borrowed from Kamisky and Schmuckler (2001), who construct indexes from 3 to 1 , from less financial liberalization to more. The degree of domestic banking liberalization is measured by four variables: the free setting of deposit interest rates, that of lending interest rates, the free allocation of credit and the permission to open foreign currency deposits, but it mostly focus in the first two.

The degree of capital account liberalization is measured by four variables: the possibility of offshore borrowing by domestic financial institutions, that of offshore borrowing by non-financial corporations, the absence of multiple exchange rate markets and that of controls on capital outflows.

Finally, the degree of liberalization of stock markets is measured by the possibility of acquisition of shares by foreigners and the capacity of repatriation of capital, interest and dividends. Given the rather general components of the liberalization indexes, particularly as regards the stock market, the information shown in the indexes will not match reality fully, but can serve as a useful basis for a broad comparison between the two regions.

The first conclusion that can be drawn from looking into the graphs is that Asian financial systems were much smaller than the European ones when financial liberalization started. In Asia, bank

\footnotetext{
${ }^{19}$ Shirai (2001) emphasizes the role played by the banking sector in the development of corporate bond markets in several Asian countries.
} 
liquid liabilities were typically about $30 \%$ of GDP, and sometimes as low as $10-20 \%$ of GDP. Credit to the private sector was lackluster in Asia but, to a lesser extent, also in Europe. The relatively low level of private credit in Europe compared to liquid liabilities shows that funds were not being intermediated properly either (graphs 4 for private credit and graph 1 for bank liquid liabilities)

G4 Credit to the private sector in the Euro area and Asia (as a share of GDP)

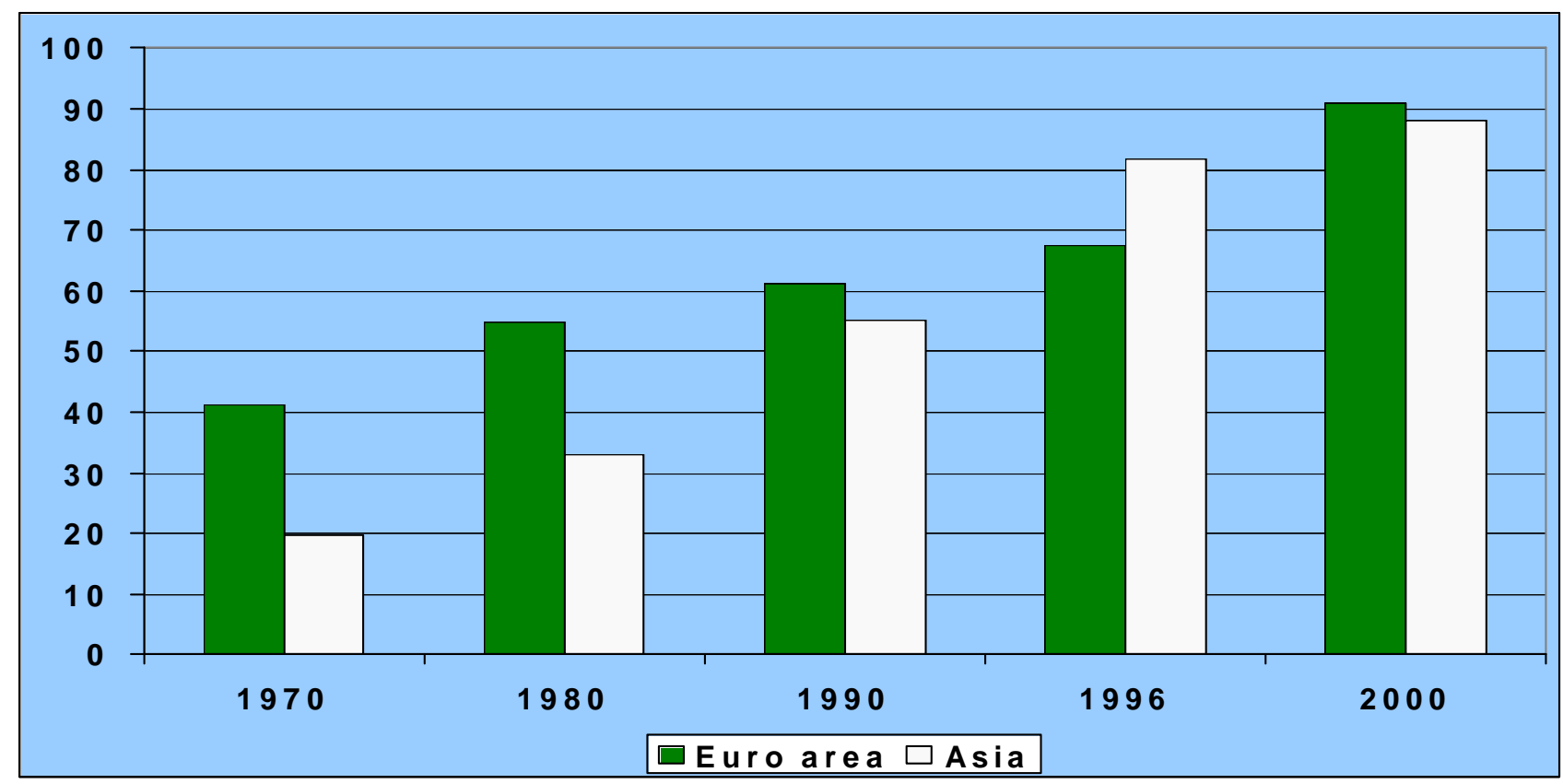

Source: Beck 1999, ECB (2001)

Note: Consolidated data for the euro area from 2000

Second, graphs 5 to 13 show that financial liberalization started earlier in the selected countries in Europe $^{20}$ than in Asia, in all its fronts (domestic, capital account or stock market). European financial systems had remained relatively subdued until the beginning of the 1980s. Then, domestic financial liberalization was accomplished relatively swiftly and without reversals in a number of countries (France, UK and Germany) but took longer in others such as Spain or Italy. On average, domestic financial liberalization in Europe was mostly completed in less than 5 years. The period would clearly be shorter if we exclude Italy and Spain from this calculation. Capital account liberalization, in turn, typically lagged domestic financial liberalization, and was also more gradual, with the exception of the UK, lasting an average of 5 years in the region. Finally, European countries opened their stock markets to foreign investors as early as the beginning of the $1970 \mathrm{~s}^{21}$. This was generally earlier than they opened their banking system to foreign entry, and also earlier than other external transactions of the capital account.

\footnotetext{
${ }^{20}$ We have selected Germany, France, Italy and the UK among European countries for this exercise, and will add Spain in the next section.

${ }^{21}$ Note that other aspects of stock market liberalization took place in the 1980 s and even the 1990s in some countries.
} 
G5 Germany: financial liberalization, banking crises and financial depth (as \% of GDP)

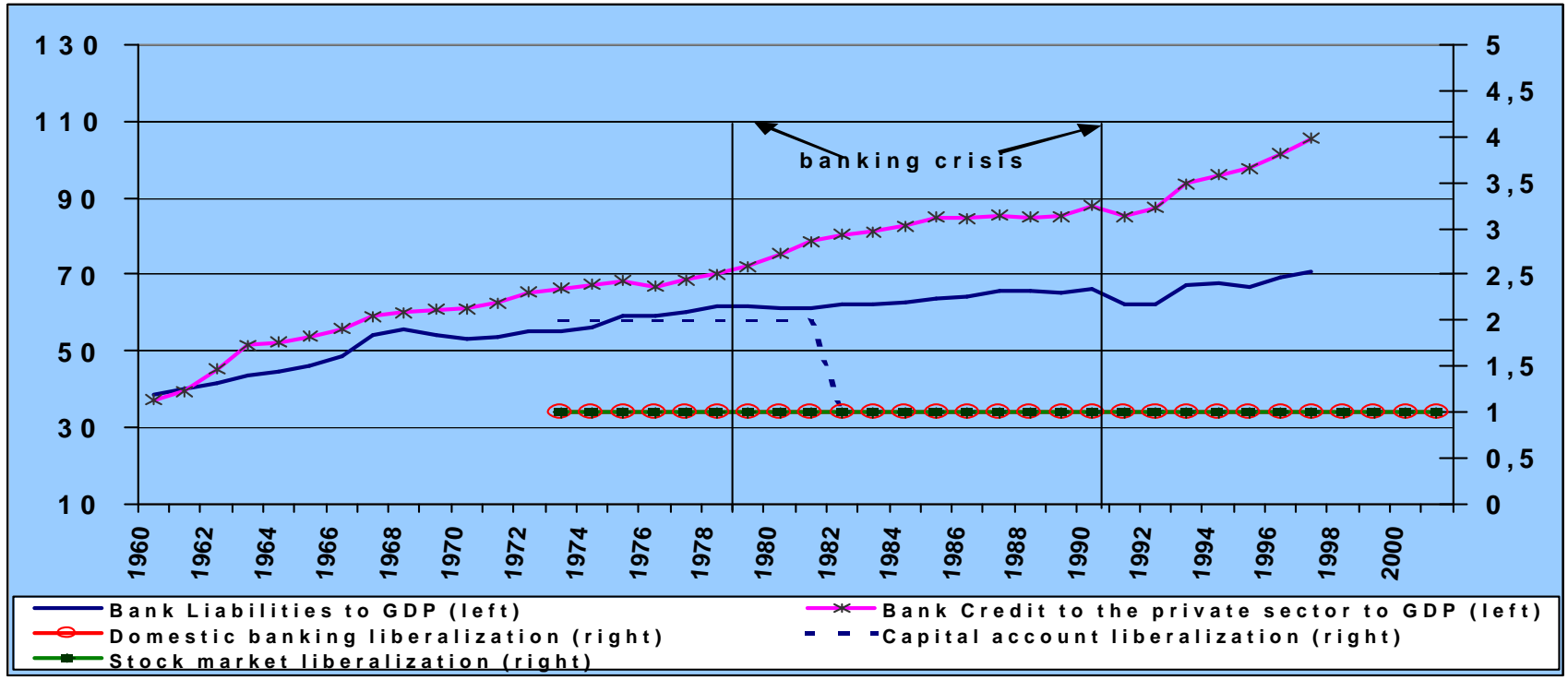

G6 France: financial liberalization, banking crises and financial depth (as \% of GDP)

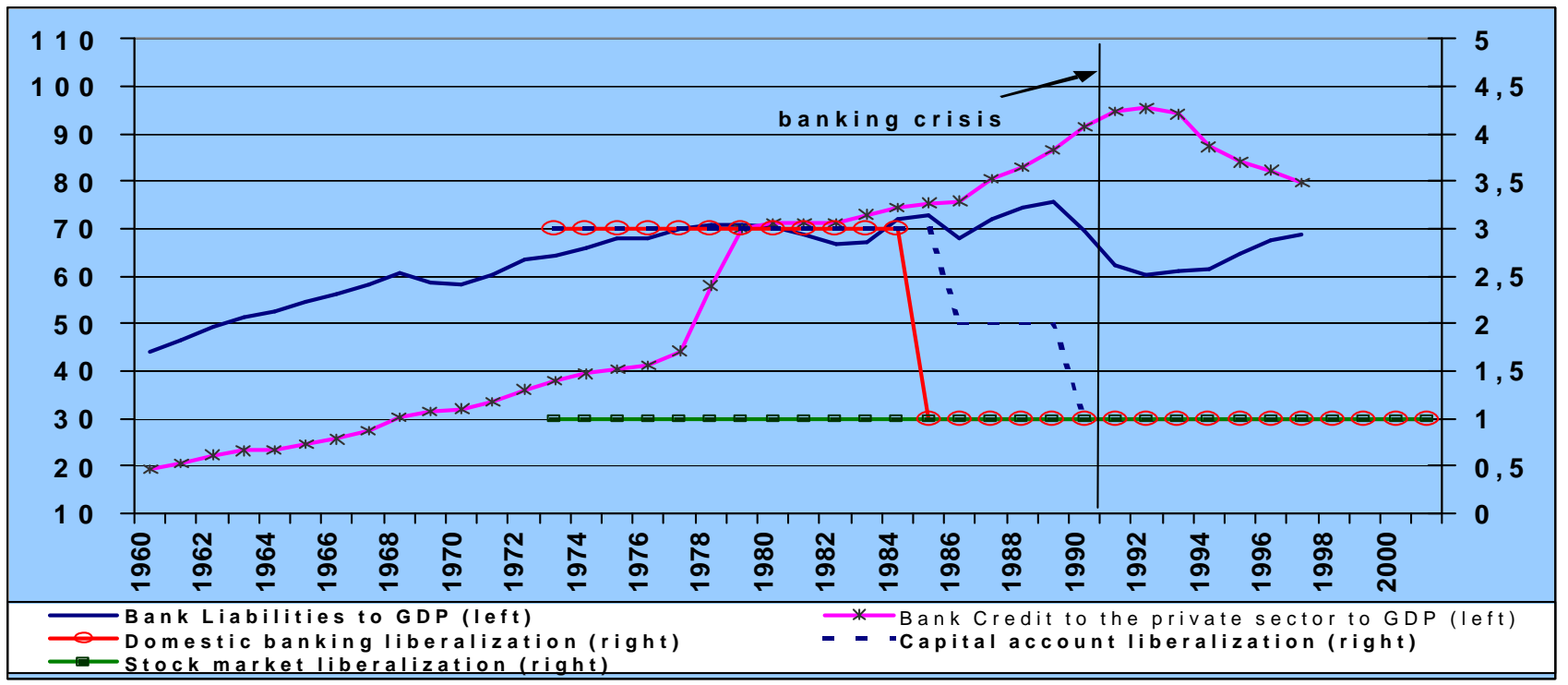

G7 UK: financial liberalization, banking crises and financial depth (as \% of GDP)

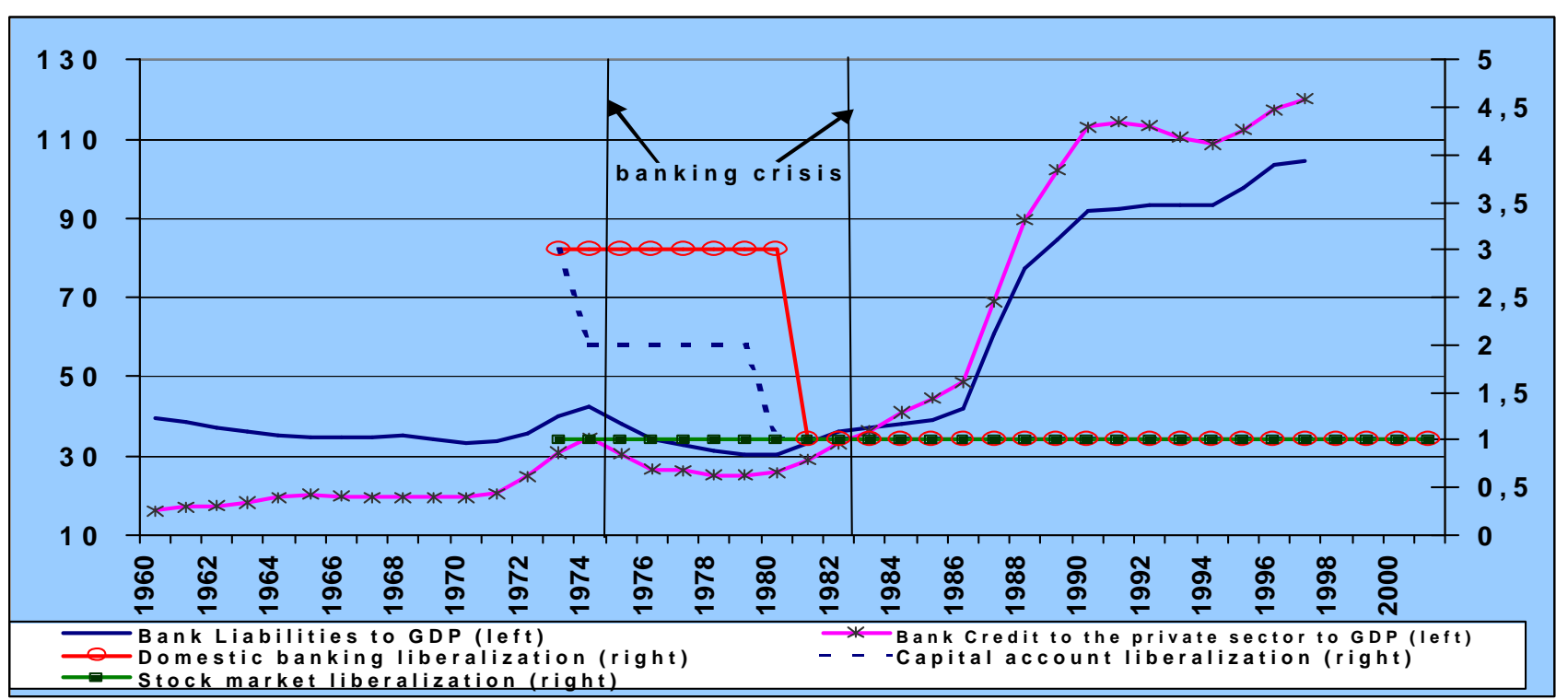


G8 Italy: financial liberalization, banking crises and financial depth (as \% of GDP)

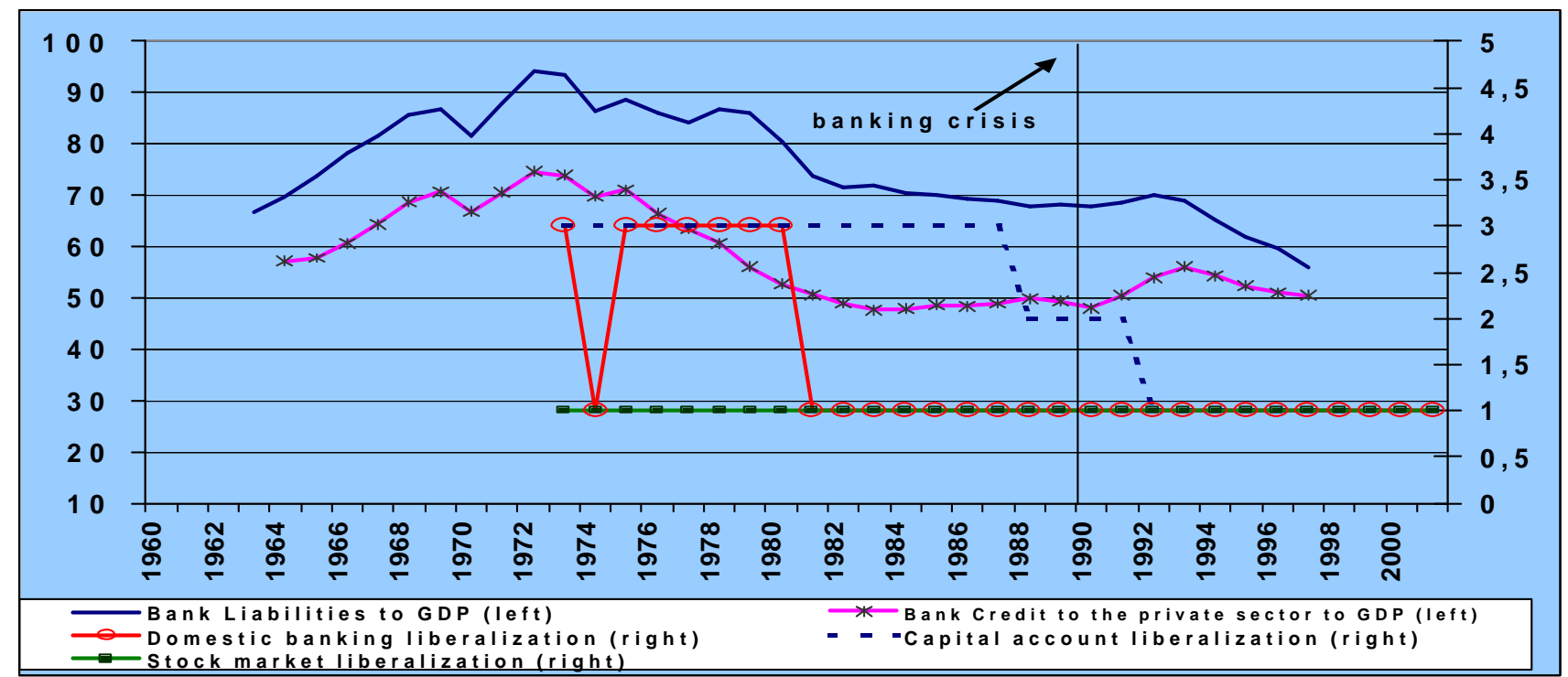

Source for G5 to G8: IFS 2001, Beck 1999, and Kaminski and Schmuckler 2001

In Asia, in contrast, the extent of financial liberalization in different countries has been much more mixed. While most countries started to liberalize their domestic financial sectors towards the mid 1980s, in several cases such as Korea or Taiwan, it remained limited in scope for many years. Others such as China have not yet liberalized significantly. There are also some exceptions, such as Malaysia or Indonesia, where deregulation of their domestic financial sectors started relatively early, towards the end of the 1970s, but experienced reversals along the way. The duration of financial liberalization processes in Asia was thus typically longer than in Europe, (with an average 7 years for the countries reviewed as compared to the average 4 years in Europe), with a few exceptions such as the Philippines or Thailand where domestic financial liberalization was swift.

As for the sequencing of reforms, it appears that many countries in Asia also started to liberalize their domestic financial systems before the capital account, in line with the general consensus in the economic literature, and finally liberalized the stock exchange. However, there are exceptions to this rule (Indonesia and Thailand) ${ }^{22}$. Furthermore, the many reversals in the liberalization process make it even more difficult to find a clear pattern. It should be noted that the more gradual process of financial liberalization in Asia was in most cases a policy decision to favor a particular pattern of resource allocation, mostly towards export-oriented economic development. ${ }^{23}$

\footnotetext{
22 Johnston et al. (1997) review the consequences of the different sequencing of Indonesia and Thailand's financial liberalization processes and find that at least in the case of Indonesia, it contributed to restructuring the domestic financial system. It should be noted however that this paper was finalized in the wake of Thailand's financial crisis while Indonesia's was still to come.

${ }^{23}$ There are different views on the costs and benefit of such choice. While Greenwood (1986) argues that using the financial system, instead of fiscal means, to achieve a desired resource allocation jeopardizes efficiency in other sectors of the economy, Chul Park (1993) argues in favor of a slow liberalization process in the cases of Korea and Taiwan on
} 
G9 Indonesia: financial liberalization, banking crises and financial depth (as \% of GDP)

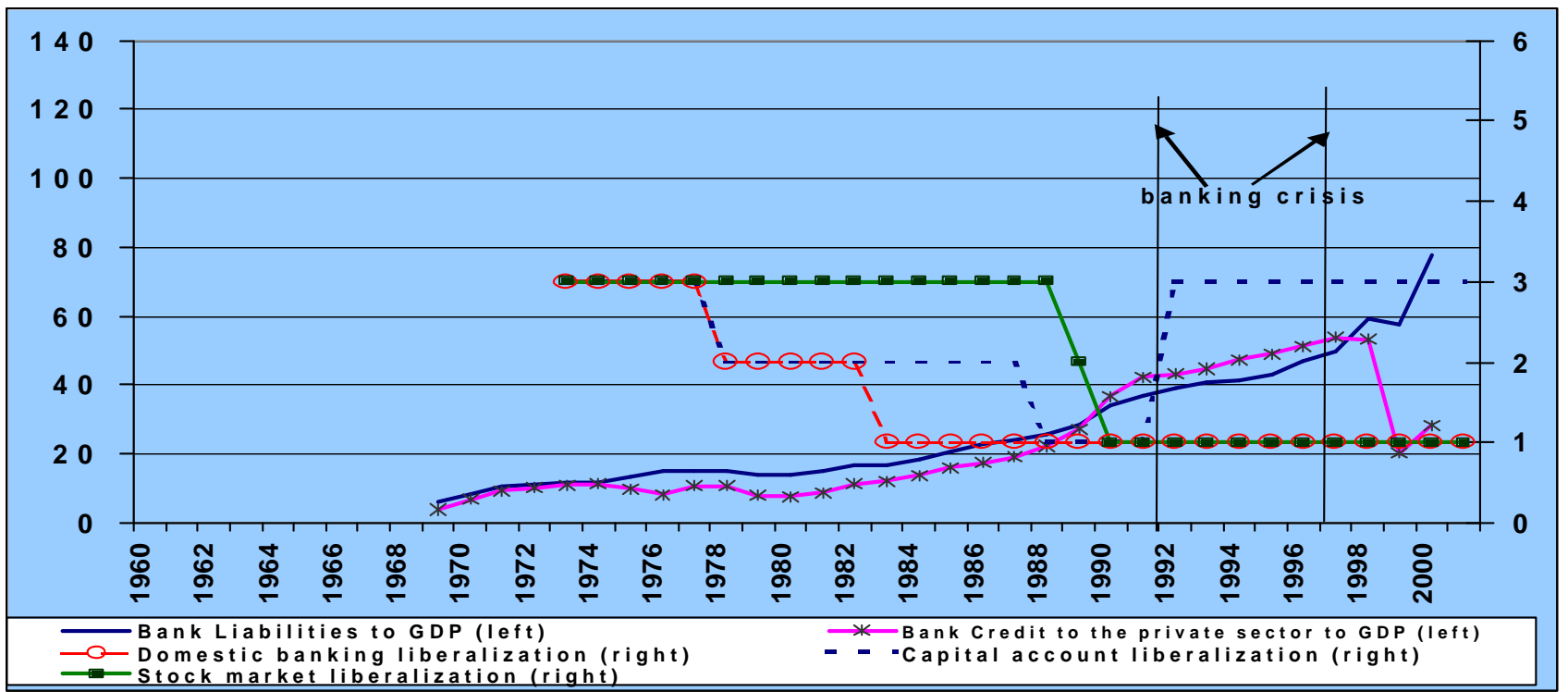

G10 Thailand: financial liberalization, banking crises and financial depth (as \% of GDP)

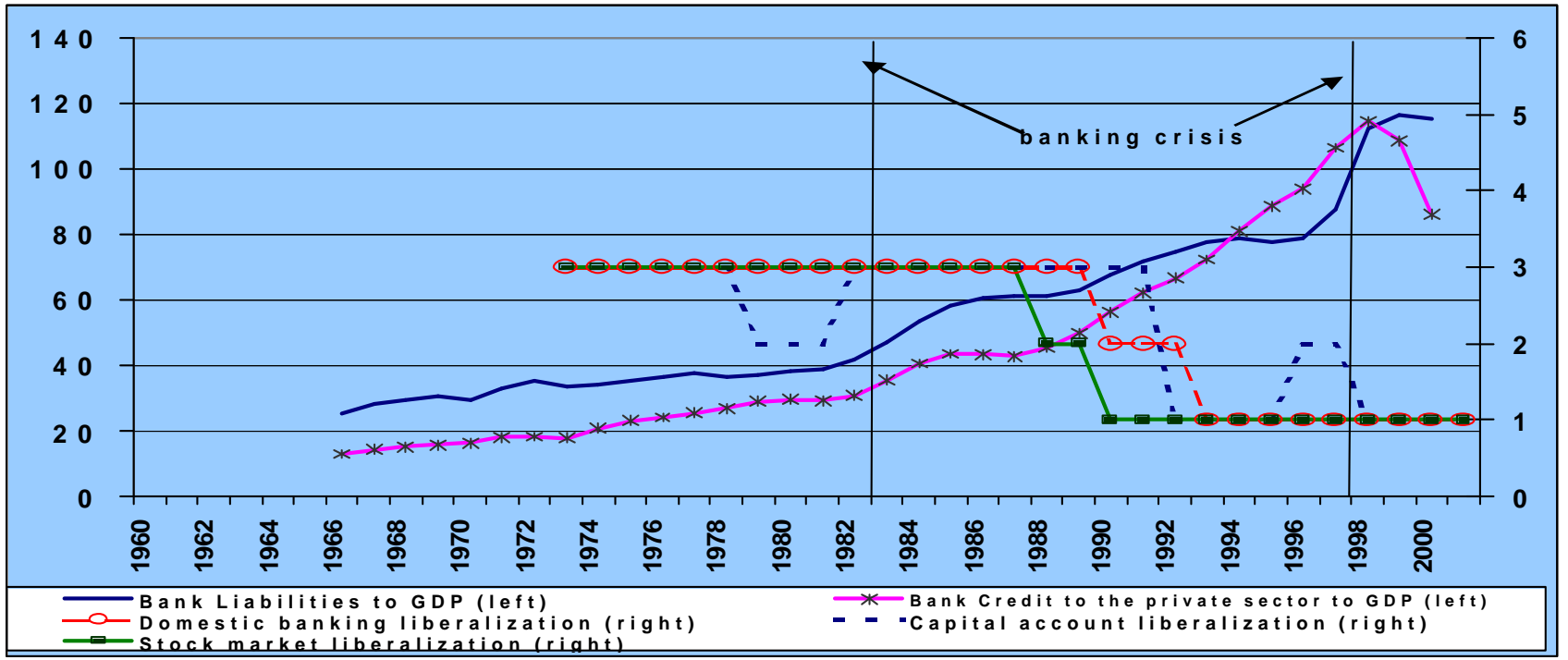

the basis that government intervention allowed for credit allocation conducive for the development of an export-oriented real sector. 
G11 South Korea: financial liberalization, banking crises and financial depth (as \% of GDP)

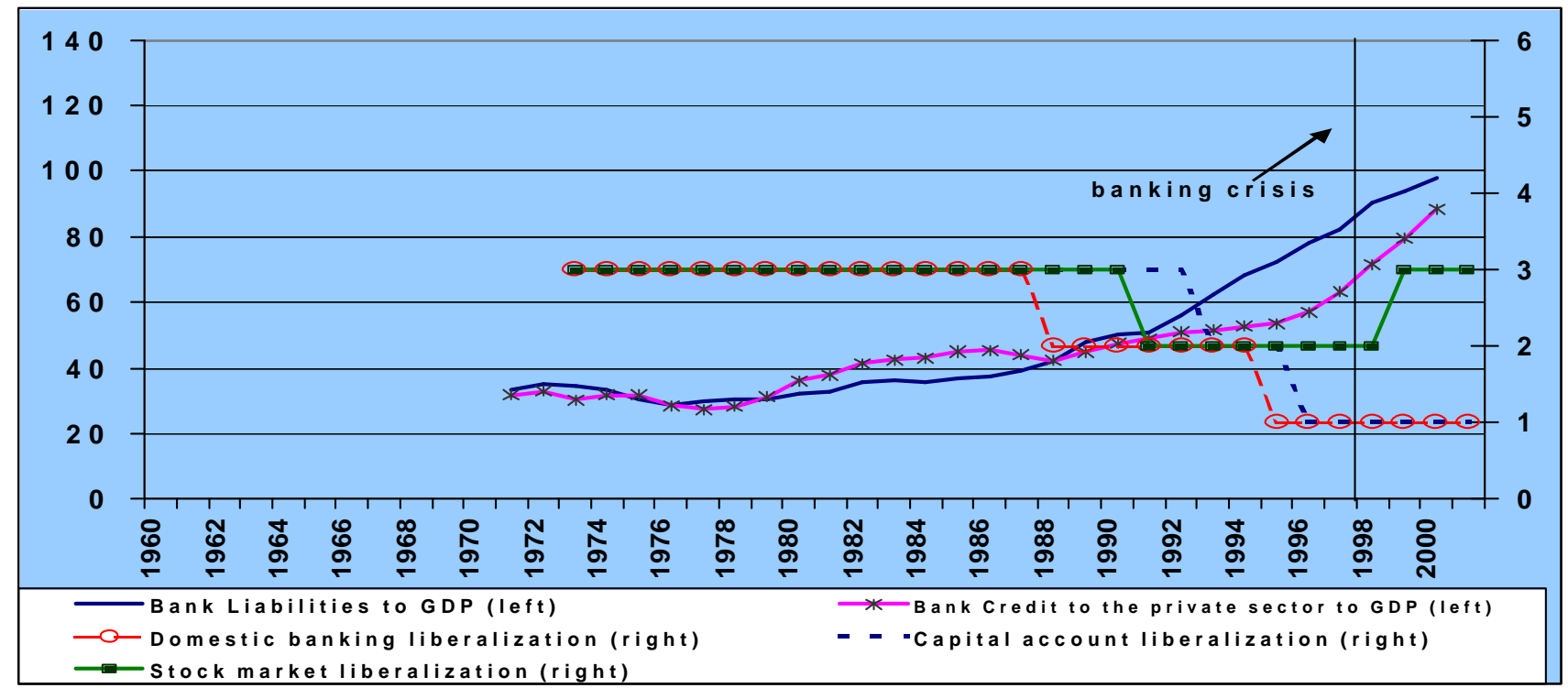

G12 Malaysia: financial liberalization, banking crises and financial depth (as \% of GDP)

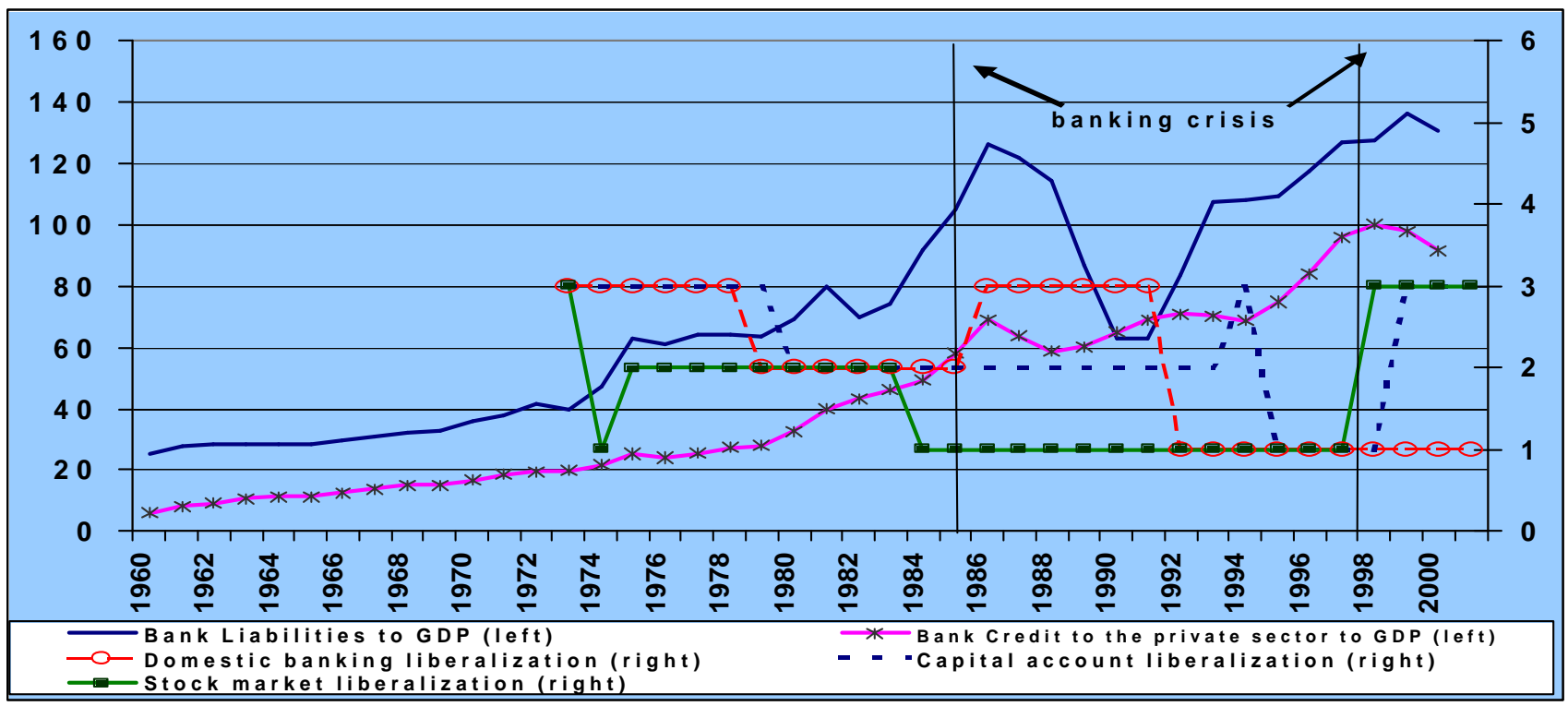


G 13 The Philippines: financial liberalization, banking crises and financial depth (as \% of GDP)

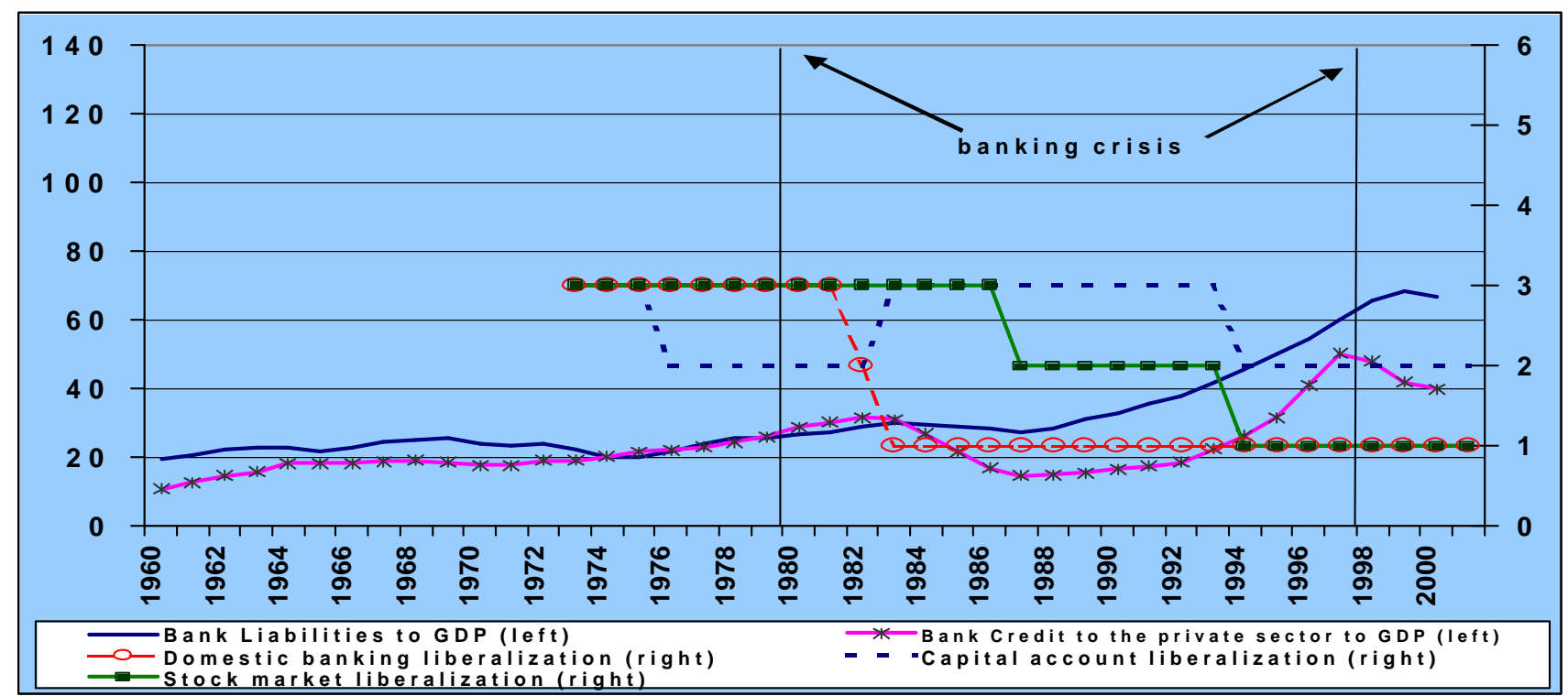

Source for G9 to G13: IFS 2001, Beck 1999, Kaminski and Schmuckler 2001

One of the key questions which stem from the above stylized facts is whether financial liberalization played a role in improving efficiency in the allocation of resources, and increased the supply of credit to the economy, in both regions. Evidence seems generally supportive of the fact that liberalization tended to increase the share of credit as a percentage of GDP in the European economies even faster than bank liquid liabilities, which allowed for a better intermediation of funds (see graphs 5 to 8 above). In Asia, a similar process seems to have taken place, although liquid liabilities have generally remained higher than credit to the private sector as a share of GDP (see graphs 9 to 13 above).

\subsection{Banking crises, the improvement in bank regulation and supervision and the DIS}

As the previous graphs already showed (vertical line in black), many countries experienced banking crises in the aftermath of financial liberalization. Most countries in Asia - and to a lesser extent in Europe - experienced at least one banking crisis, and in many cases a systemic one ${ }^{24}$. A few of them resulted in a reduction of the deposit base because of massive bank closures or, sometimes, deposit runs, mainly in Asia. The causes of these crises were of very different nature, but there was at least one common development: an accelerated growth of credit to the private sector following, in many instances, financial liberalization. This happened, to a different extent, in France, Spain, UK, and in all Asian crises countries in 1998.

From the experience with crises, it has resulted a tightening of financial regulation and supervision, particularly in Asia but also in some European countries as will be shown for the case of Spain later. While it is difficult to compare the quality of regulation and supervision among different countries, an attempt can be made using a recent database provided by the World Bank (Caprio et al. 2001), which reviews the quality of bank regulation and supervision for a very large group of countries. Attending to this survey, Asia has substantially improved its standards after the crisis 
and today stands at levels comparable to those of Europe, particularly in some countries, although there is still room for improvement.

Table 1: Deposits insurance schemes

\begin{tabular}{llcc}
\hline Countries & Type & Date Enacted / Revised & Source of Funding \\
\hline \hline EUROPE & & & \\
\hline Austria & explicit & $1979 / 1996$ & Joint \\
\hline Belgium & explicit & $1974 / 1995$ & Joint \\
\hline Finland & explicit & $1969 / 1992 / 1998$ & Joint \\
\hline France & explicit & $1980 / 1995$ & Private \\
\hline Germany & explicit & $1966 / 1969 / 1998$ & Private \\
\hline Greece & explicit & $1993 / 1995$ & Private \\
\hline Iceland & explicit & $1985 / 1996$ & Private \\
\hline Ireland & explicit & $1989 / 1995$ & Private \\
\hline Italy & explicit & $1987 / 1996$ & Joint \\
\hline Luxembourg & explicit & 1989 & Private \\
\hline Portugal & explicit & $1992 / 1995$ & Joint \\
\hline Spain & explicit & $1977 / 1996$ & Joint \\
\hline Sweden & explicit & 1996 & Joint \\
\hline United Kingdom & explicit & $1982 / 1995$ & Private \\
\hline
\end{tabular}

ASIA

\begin{tabular}{lccc}
\hline China & implicit or none & & \\
\hline Hong Kong & implicit or none & & \\
\hline Indonesia & implicit or none * & Blanket guarantee in 1998 & Joint \\
\hline Korea & explicit * & 1996, blanket guarantee in 1998 & Joint \\
\hline Malaysia & implicit or none * & Blanket guarantee in 1998 & 1963 \\
\hline Philippines & explicit & & \\
\hline Singapore & implicit or none & & \\
\hline Thailand & implicit or none * & Blanket guarantee in 1998 & \\
\hline \hline
\end{tabular}

* extended blanket guarantee to deposits in the aftermath of 1998 crisis

Source: Deposit Insurance Database (World Bank, 2000)

Another feature that distinguishes financial regulations in Europe and Asia is the existence of DIS. DIS were typically introduced either as a result of a banking crisis (as in Spain) or as financial systems became fully liberalized and bank regulation improved in the late 1970s. DIS were, then, reformed and harmonized in the 1980s and 1990s, generally moving towards an explicit and limited-coverage scheme ${ }^{25}$. Today, all European countries hold a limited-coverage and explicit DIS as shown in Table 1. About half of them are fully funded by the private sector, and the rest are funded jointly by the private and public sectors. By contrast, only two out of seven countries in Asia

(South Korea and the Philippines) had an explicit and limited-coverage DIS in place before the Asian crises. When the crisis hit, many countries, which did not have a DIS (Indonesia, Thailand and Malaysia, as well as Korea which did have a limited one), moved to extend blanket guarantees on deposits to prevent deposit runs. The smaller number of systemic crises in Europe coupled with a better design of their DIS is in line with the findings of the literature mentioned in the previous section.

\footnotetext{
${ }^{24}$ In the Europe, 11 out of 15 countries had at least one banking crisis in the period under consideration. 4 of those banking crisis were considered as systemic. In Asia, in contrast, all 8 countries in our study had banking crisis and 4 of them were considered systemic.

${ }^{25}$ The EU Deposit Guarantee Directive, which came into effect in 1995, ensures a minimum protection of 20,000 euro per deposit and compulsory membership for all credit institutions.
} 


\subsection{International - and regional- financial Integration}

We shall now compare the three main dimensions of financial integration reviewed in the previous section.

G14 Foreign bank participation in selected European and Asian countries

(as \% of total bank assets)

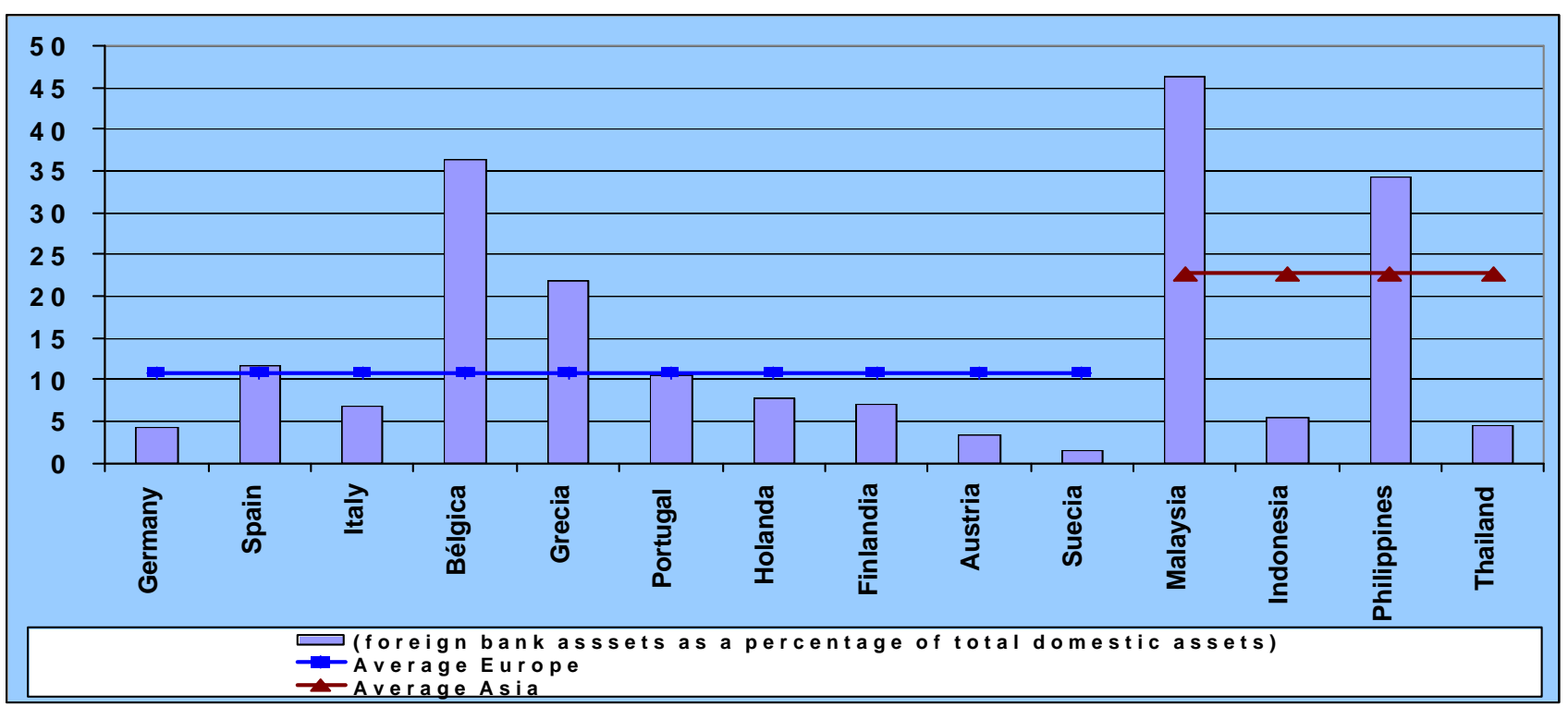

Data for 1997

Source: ECB 1999 and Beck et al (1999)

Note: Hong Kong and Singapore in Asia and Luxemburg, UK and Ireland in Europe.

(i) The opening up of the domestic banking system to foreign competition

Foreign bank participation in Asia and Europe stand at relatively low levels, when compared with other regions of the world such as Latin America, and even more so Eastern Europe ${ }^{26}$. While they average over $20 \%$ of total bank assets in Asia as shown in graph 14 , they stay at roughly $10 \%$ in Europe with the clear exceptions of the UK, Ireland or specially Luxemburg where foreign banks hold more than half of total assets. ${ }^{27}$

Although the two areas hold relatively low shares of foreign-owned banks in their banking systems, the underlying reasons are different. Asia still maintains restrictions to foreign ownership, with the exception of Hong Kong and Singapore as off-shore financial centers, while European countries have practically fully liberalized foreign entry ${ }^{28}$. This has been particularly warranted in the run-up

\footnotetext{
${ }^{26}$ Shares of foreign banks stand well over $50 \%$ of total bank assets in these regions.

${ }^{27}$ In the two regions, special cases have been excluded from the average, namely Hong Kong and Singapore in Asia and Luxemburg, UK and Ireland in Europe.

${ }^{28}$ The First Banking Directive, and especially the Second Banking Directive have introduced provisions for mutual recognition, home country supervision and the elimination of capital requirement for branches within other EU countries.
} 
to a Single Market in Europe, in order to profit from economies of scale and scope. In fact, the First Banking Directive, and especially the Second Banking Directive have introduced provisions for mutual recognition, home country supervision and the elimination of capital requirement for branches within other EU countries. In addition, by granting a single passport the Second European Directive provides a large incentive for harmonization. Finally, European countries have decided unilaterally to lift restrictions on branching of all or some institutions. Notwithstanding the regulatory efforts towards more foreign participation in the domestic banking systems in most countries, extensive branching and very well established domestic franchises have acted as a deterrent to foreign participation in many European countries. A strong preference for local banks also seems to exist in many European countries as well as some non-legal barriers to entry in particular countries (Gual, 1999).

\section{(ii) Outward internationalization}

Another important angle of the international integration of a banking system is the amount of assets it holds abroad. In this regard, BIS consolidated banking statistics provide a good indication of the degree of outward internationalization of financial systems of the 23 reporting countries based on information on total foreign claims by country and by world region, both in local and foreign currency. BIS total figures include data from three Asian reporting countries (Hong Kong, Singapore and Taiwan) but unfortunately, this is not yet disaggregated by country. Disaggregated data for European countries is in turn available. Therefore, using BIS figures we can learn about the degree of internationalization of most European countries, but not of Asia as of yet. ${ }^{29}$

Graph 15 shows the increasing participation of European banks in foreign banking systems, which may be partially explained by diversification efforts in the run-up to monetary union, and by excess liquidity or capacity of European banks because of increasing market saturation and low returns in the area $^{30}$. As a result, European banks appear to have acquired a leading role as international lenders, their foreign claims amounting to $53 \%$ of all international bank lending. However, it is remarkable that total foreign claims of European banks to Asia show just a meager $4 \%$ of total international lending. Low levels of integration in Asia are also evident when we look at the degree of outward internationalization of Japanese banks. While Japanese banks are relatively active international lenders at the aggregate level (10\% of total international claims), their exposure to Asia amounts to just $1 \%$ of total international consolidated claims, a level close to that of the US or Germany but lower than for example that of the UK.

\footnotetext{
In addition, by granting a single passport the Second European Directive provides a large incentive for harmonization. Finally, European countries have decided unilaterally to lift restrictions on branching of all or some institutions.

29 Total foreign claims include cross-border claims plus local claims of reporting banks' foreign affiliates in foreign and local currency, but are not collected on a net basis and only show the asset side of the consolidated balance sheet.

${ }^{30}$ See ECB 1999.
} 


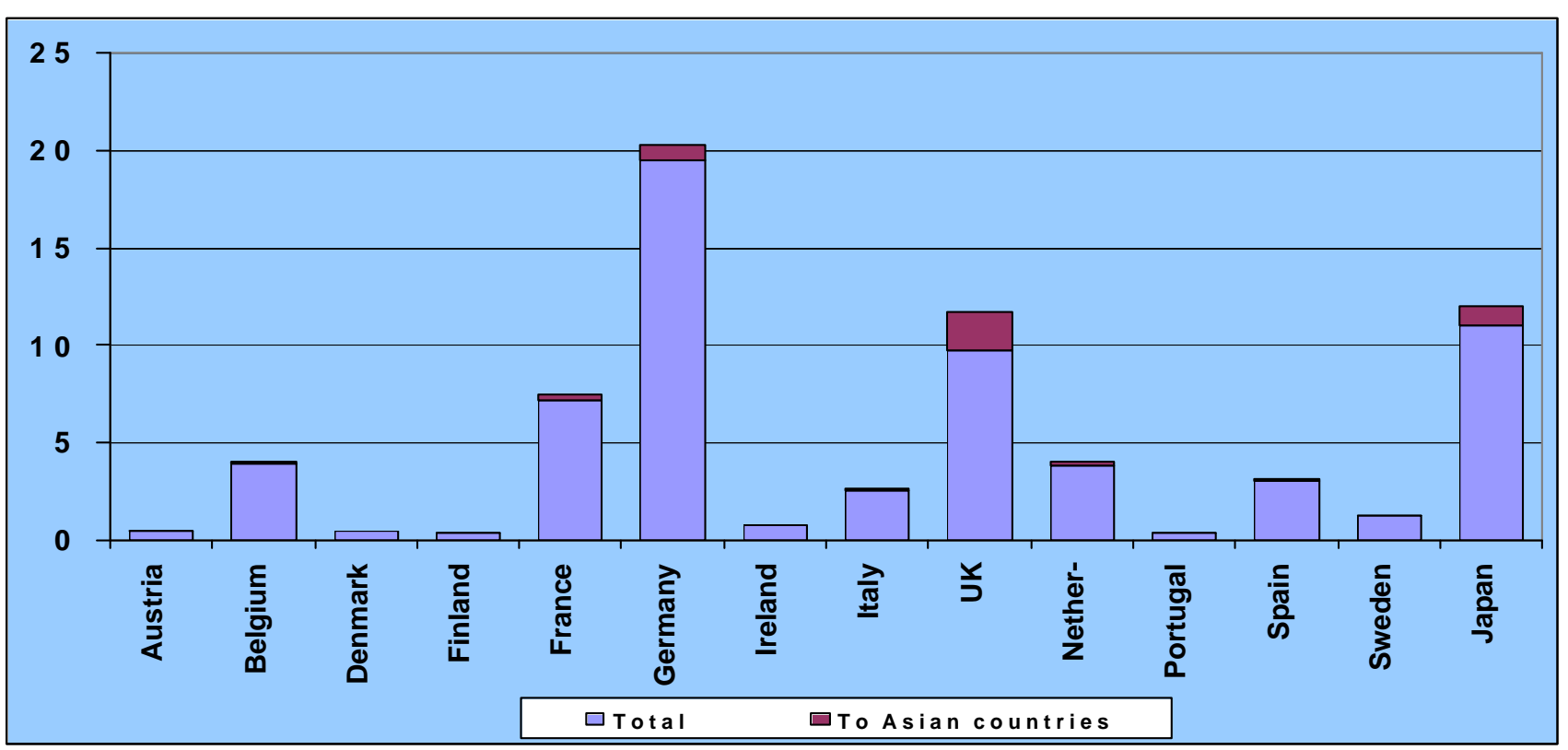

Data for 2000

Source: BIS (2001)

\section{iii) Regional Integration Efforts in markets and infrastructure}

This is obviously the area in which the differences between Asia and Europe are most striking. Europe has moved forward in terms of financial market integration since the introduction of the Single Market, and particularly since the creation of EMU. Today, there is a single monetary policy and money markets have become fully integrated. Government debt markets have become more harmonized with the consequent reduction of spreads among different euro area countries. However, there is still wide room for improvement when comparing the euro area financial markets with those of the US, a natural benchmark for an integrated financial system. Retail banking remains largely domestic, although efforts towards Pan-European banking are starting to emerge. There still no fully harmonized regulatory framework ${ }^{31}$ and infrastructure since several different clearing and settlement systems remain in place. In addition, the relatively strong degree of home bias is reflected in a low volume of intra-EMU cross-border credit transfers, as well as the low share of foreign assets in the total assets under management in institutional portfolios and the small value of cross-border listings in the European stock exchanges.

\section{The case of Spain}

EU accession in 1986 marked a crucial turning point for Spain, both in terms of economic growth and of financial sector development. Since 1986, Spain real GDP per capita in PPP terms has increased by over 10 percentage points relative to the European average in less than 15 years. Financial depth as measured by the ratio of credit to the private sector to GDP has soared from $55 \%$ to over $90 \%$ in 2001 , something that clearly indicates a key contribution of the financial sector to Spain's catching-up with the rest of the EU. In turn, financial sector depth has grown somehow

\footnotetext{
31 European regulation is harmonized in terms of minimum standards to provide a level playing field. This includes solvency ratios, the definition of own funds, large exposures and others but many countries have adopted more stringent regulation than that proposed by European legislation.
} 
more moderately in European countries such as France or Germany (see graphs 5 to 8), which had already reached higher GDP per capita standards.

Several features stand out when comparing Spain with the banking systems of other European countries $^{32}$. First, its size is still somewhat smaller than the European average when measured in terms of assets, loans or deposits. Measured by number of financial institutions, the banking system appears larger, accounting for over $15 \%$ of all European financial institutions.

The number of bank branches per inhabitant is the largest in the EU, a feature that possibly indicates some degree of "overbranching". However, Spain's relatively low population density explains, at least in part, the larger number of branches needed to provide similar financial services. ${ }^{33}$ In this regard, another important feature of the domestic banking system is the high number of ATMs per inhabitant, the highest in the EU (0.88 per 1000 capita versus 0.44 EU average) .High ATM density together with rather intensive investment in technology has allowed Spanish banks to improve efficiency and reduce the number of bank employees per inhabitant below the EU average (6.29 per 1000 capita versus 9.73 EU average $)^{34}$.

Foreign bank participation is larger in Spain than in other European countries such as Italy, France or Germany, but it is still small in absolute terms and has actually fallen over time because of the not too successful results of many of the foreign banks having entered the Spanish banking system. Spain is also one of the countries with more foreign branches and subsidiaries abroad, a feature underlining the strong internationalization process of the last half of the 1990s.

In terms of bank concentration, Spain occupies an intermediate position either measured by the concentration of the five largest banks assets (see Graph 16) ${ }^{35}$. Spain ranks below smaller countries in terms of concentration but over large countries such as Germany or Italy where consolidation has lagged behind.

Concentration appears on the rise as of late as most of the largest Spanish banks have merged, although the Spanish financial system still comprises a relatively diverse number of large, medium and also small regional financial institutions, which contributes to ensuring a high degree of competition.

\footnotetext{
${ }^{32}$ In order to compare the Spanish banking system with other European countries we use ECB (1999, 2000a and $2000 \mathrm{~b})$. Although the information of the latest years is not included, the broad picture has not changed substantially. .

33 See Fuentelsaz and Salas (1994) for such an argument. In addition, some evidence supports the view that retail consumers have been ready to trade off interest rate for more proximity in bank branches. Branches may thus reinforce brand loyalty (higher switching costs) and act as a deterrent to competitor's entry.

${ }^{34}$ The last two indicators can be found in ECB (1999).

${ }^{35}$ The same result is found when using the Herfindahl index.
} 
G16: Bank concentration in selected EU countries

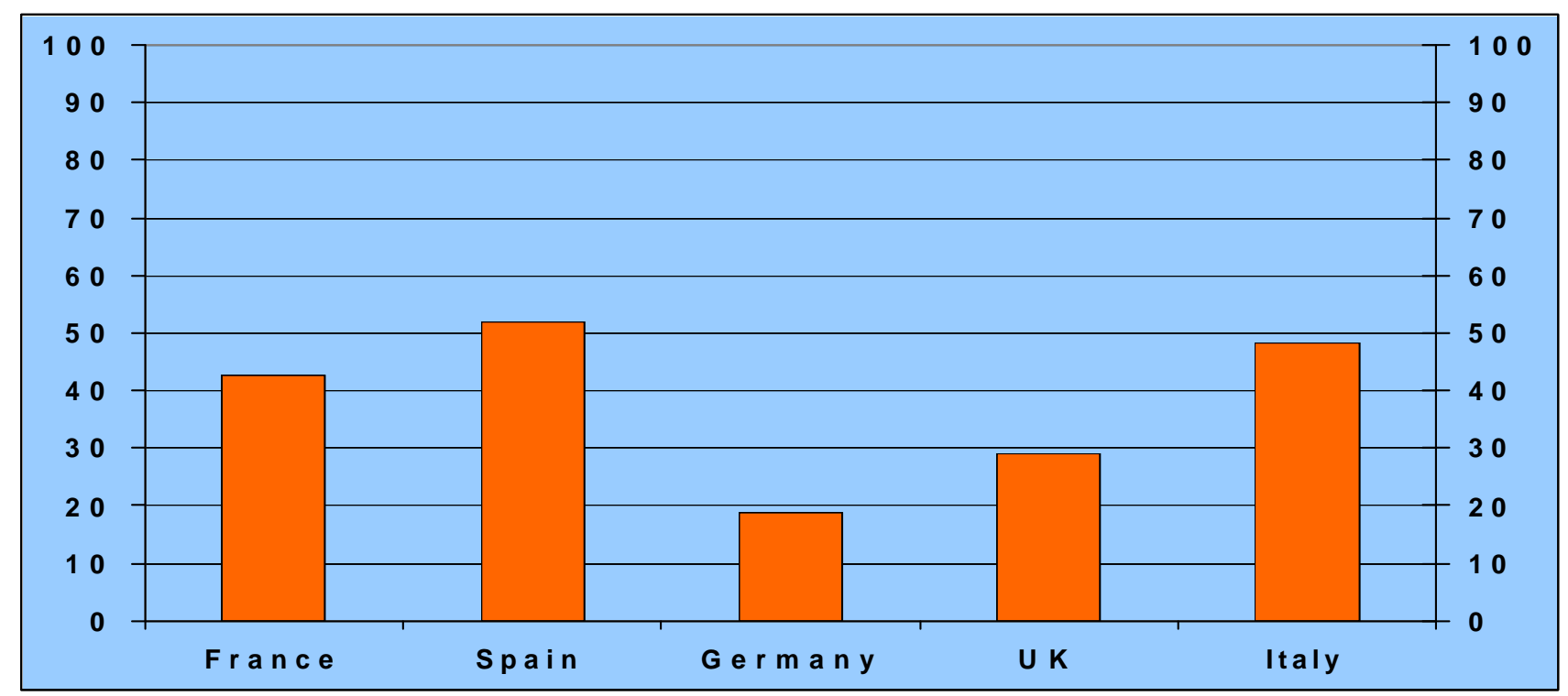

Data for 1999

Source: ECB (2000b)

Note: Concentration is measured by the five largest banks' assets to total assets

Two large commercial banks and two large savings banks are the major players in the Spanish financial system ${ }^{36}$. In terms of consolidated assets, the distance between the two banks and the rest of banking groups is important and even growing, since these two banks have almost entirely led the internationalization process of the Spanish financial system. However, in terms of market share in the domestic market, differences are smaller.

Banks in Spain rank well in terms of profitability relative to European standards. In the last few years, operating income as a percentage of total assets, although declining, has been clearly above the average of the Euro Area, and even European Union countries, Bank efficiency, measured by operating costs to operating income, is about average. And the return on equity $(\mathrm{ROE})$ and the return on assets (ROA) of Spanish banks have consistently remained well above the euro area average during the last years of available data Spanish banks also do well in terms of solvency. Capital adequacy ratios are about the EU average. This is even more so if one considers that the Spanish regulator, namely Banco de España, requires tighter capital standards than in most other European countries ${ }^{37}$

\footnotetext{
${ }^{36}$ Apart from these four institutions there are other nationwide banks that are gaining market share after the mergers of the largest banks. Medium size regional savings banks and some national commercial banks are also important participants that hold strong franchises in their region and typically outperform nationwide banks in terms of market share. Finally some local and specialized banks plus cooperative banks in rural areas complete the financial landscape.

37 The difference is not in the denominator of the ratio (i.e., the weighting of different assets) but the definition of capital. Tier 1 definition is almost the same. However, Spanish regulators do not allow counting general provisions and undisclosed reserves as Tier 2.
} 
G17 Operating income as a percentage of total assets in selected EU countries

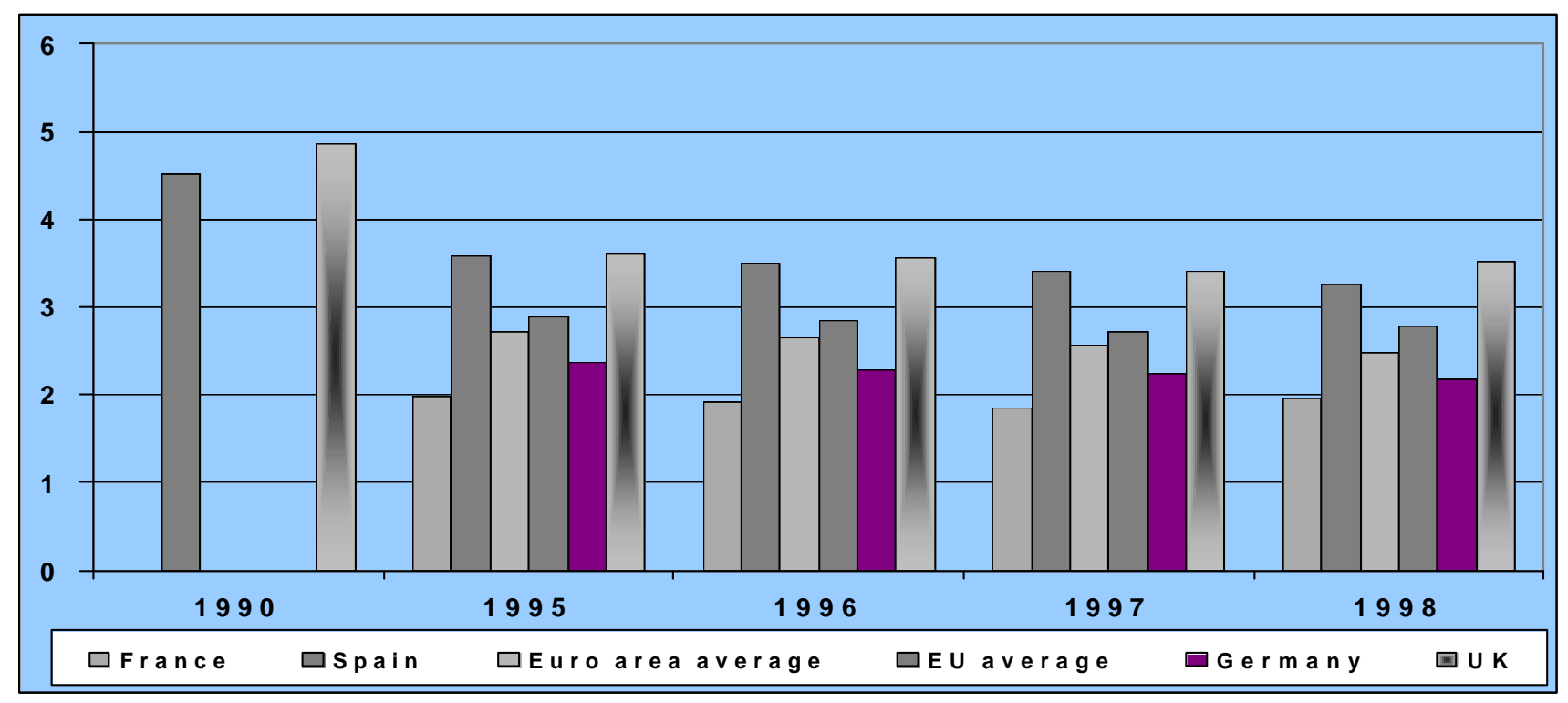

Data for 1998

Source: ECB 2000a

G18: Operating costs to operating income in selected EU countries

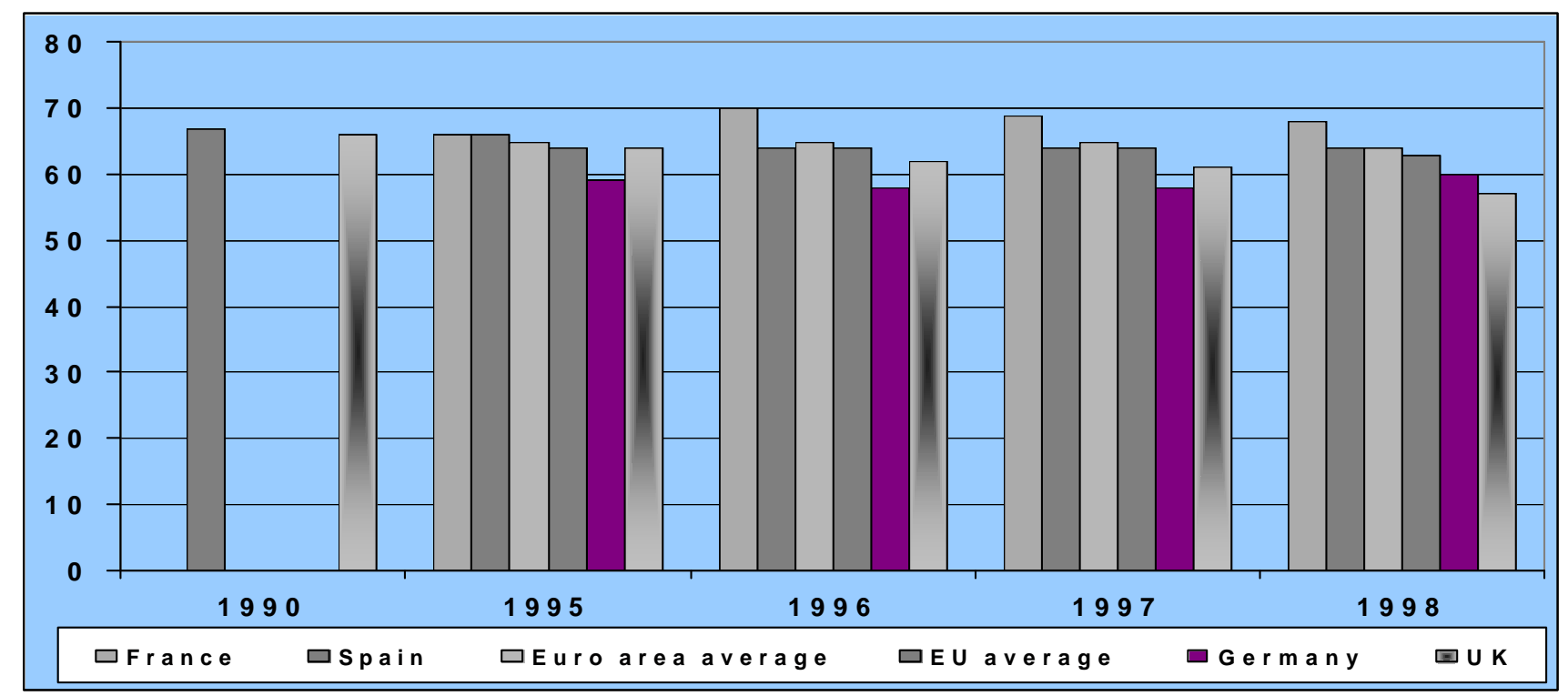

Data for 1998

Source: ECB 2000a 
G19 Return on equity in selected EU countries

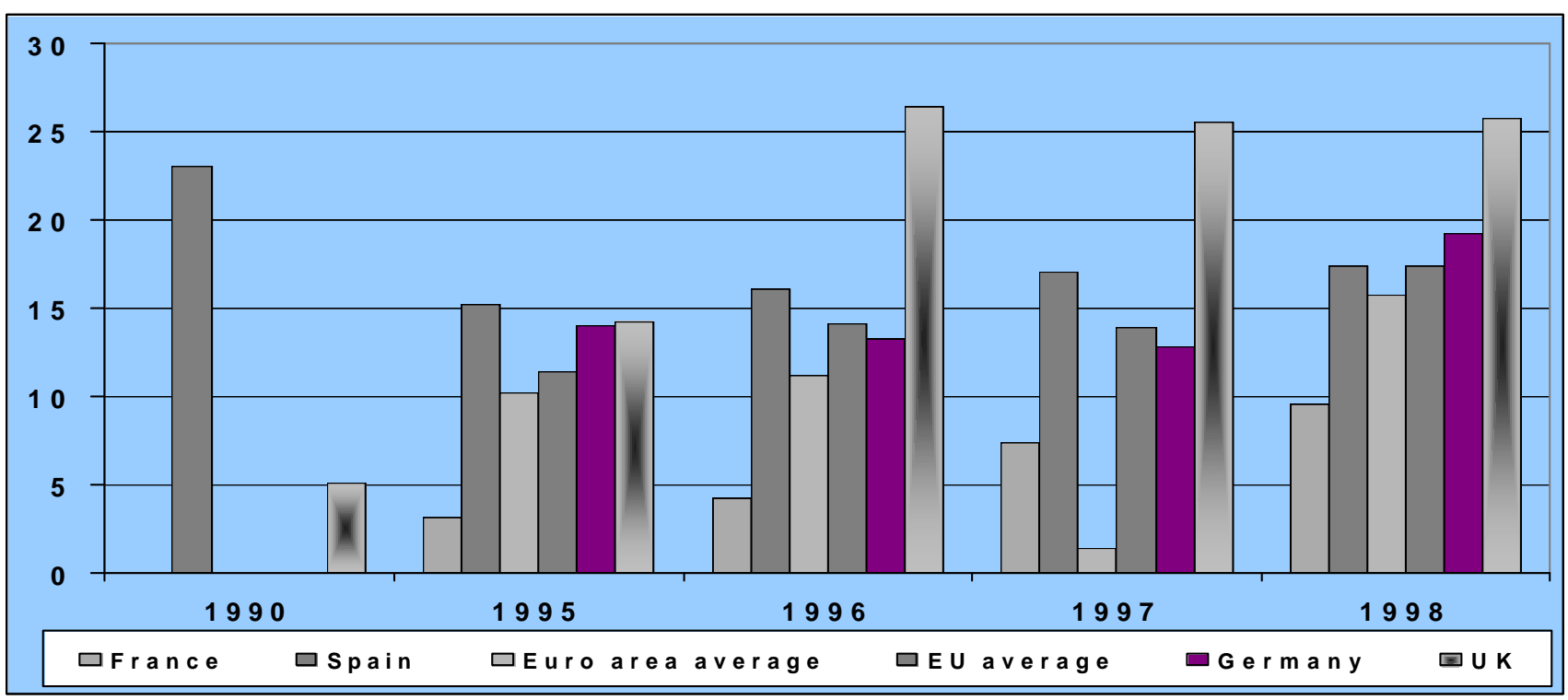

Data for 1998

Source: ECB 2000a

G20 Return on assets in selected EU countries

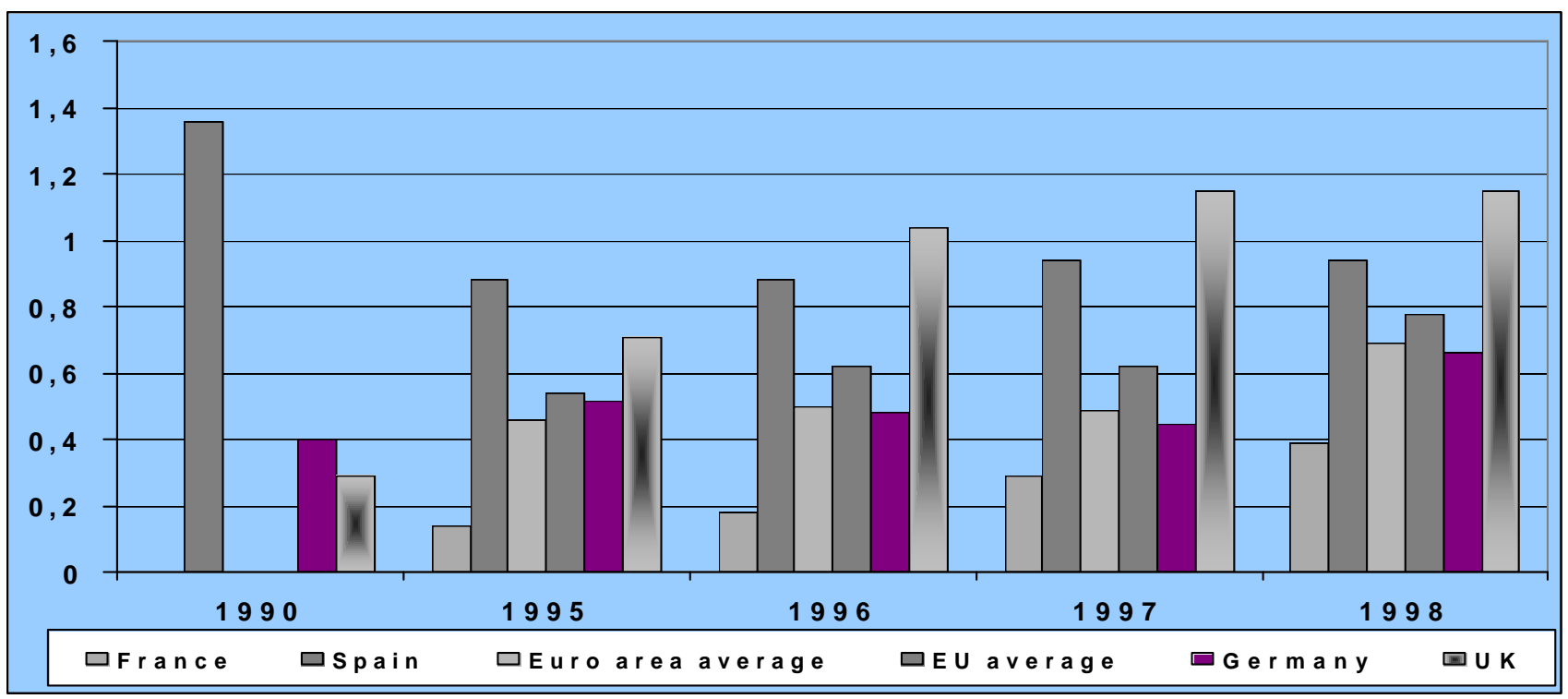

Data for 1998

Source: ECB 2000a

If measured by Basel standards, the capital ratio of Spanish banks would appear, on average, a $20 \%$ higher than with the national standards.

The high level of capital held by banks is one of the main factors behind the soundness of the Spanish banking system but not the only one. Banco de España has also introduced a new, socalled "statistical", provision to be added to the existing specific and general provisions. The statistical provision aims at covering expected losses dynamically from the moment a loan is made. This should, first, reduce the procyclical nature of other provisions and, second, result into profit and loss accounts that better reflect correlations between income and expenses through the life of 
a loan ${ }^{38}$. The statistical provision should, thus, allow banks to react to an economic slowdown from a better position.

Finally, another remarkable feature of the Spanish financial system is the fact that banks manage a very high percentage of investment fund assets in terms of GDP (among the highest in the EU). Tax changes and strong banking competition explain the fact that investment funds started to grow very rapidly at the beginning of the 1990s but kept being managed by banks or bank subsidiaries in a very large proportion ${ }^{39}$. Pension funds are also for the most part managed by banks, although they are very small in comparison to other European countries. Tax and liquidity reasons also explain this feature. As a result, the fact that the development of capital markets, and in particular of institutional funds, has been led by banks implies that there has been no real disintermediation process, as has happened in some other European countries.

Several crucial issues have occurred in the Spanish banking system since the 1960s, which explain this positive development. First, financial liberalization, after a decade of financial repression. Second, the banking crisis, which was more related to bank mismanagement than financial liberalization although the latter certainly did not help. Third, the blurring of the difference between commercial and saving banks. And, finally, the rapid international - and regionalintegration process, with the participation in, and acquisition of, banks abroad, particularly in Latin America, and the always closer integration within the European banking system.

\subsection{Financial liberalization}

The Spanish banking system was tightly regulated until the end of the 1960s. All interest rates both in the asset and the liability side of the banks' balance sheets were set administratively. There was directed credit at below market rates to sectors such as agriculture, shipbuilding and housing. The number of branches that a bank could open was also regulated by a system of quotas distributed among incumbent banks. Foreign banks were not allowed to operate in $\operatorname{Spain}^{40}$.

In addition, there was a tight regulation separating the functions of commercial and savings banks. The former focused on financing the corporate sector, and was allowed to operate in the foreign exchange market, but not to provide other financial services such as mortgages. Savings banks, in contrast, focused on lending to households (especially mortgages) but were not allowed to operate with the corporate sector. In addition, savings banks were primarily regional franchises and were not allowed to expand geographically outside their region of origin.

To sum up, during the 1960s, a significant amount of decisions, as well as business orientation, were kept away from Spanish banks' managers, and remained the competence of regulators. This,

\footnotetext{
${ }^{38}$ A detailed rational for the statistical provision, the way it works and the objectives it covers can be found in Fernandez de Lis et al (2001).

${ }^{39}$ This is not too different to some Asian countries, as Shirai (2001) recalls.

${ }^{40}$ Except for four banks which were already operating in the country before the forties. In any case, the market share of those four banks was almost negligible.
} 
among other factors, resulted in an oligopolistic structure with large economic rents for incumbent banks but with a large welfare cost for investors and depositors ${ }^{41}$.

G21: Financial liberalization, the banking crisis and financial depth in Spain 으으으으응

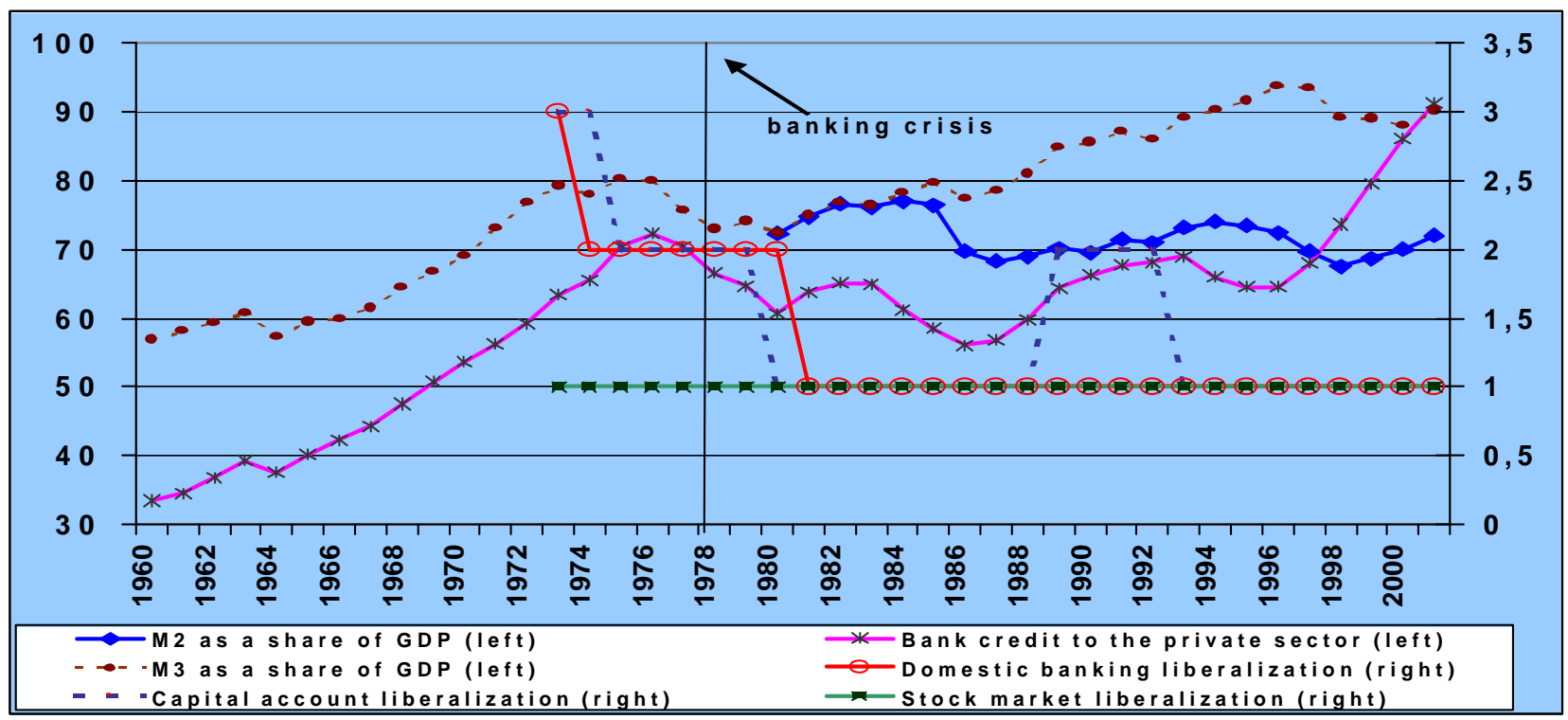

Source: Banco de España; Kaminski and Schmuckler (2001)

Policy makers realized that liberalizing the financial system was needed in order to enhance competition and efficiency. The financial liberalization process started formally in 1969, although it only gathered speed in the early 1970s, and ended towards the end of the 1980s - beginning of the 1990s. Financial liberalization was by no means a linear process in Spain, as summarized in Table 2, but rather lengthy and with reversals, but at the end Spanish banks were allowed to freely determine interest rates on their assets and liabilities. Captive investments disappeared (except for a small reserve requirement), geographical restrictions to branch opening were lifted first for commercial banks and eventually also for the savings banks, and foreign banks were licensed to operate in Spain.

The liberalization of the banking system was meant to increase competition. However, as increased competition eroded economic rents ${ }^{42}$, it also enhanced the bank incentives to adopt riskier policies. A lower franchise value, stemming from bank deregulation and increased competition, provided less of an incentive for banks to reinforce their solvency through capital. The likelihood of a banking crisis to occur was, therefore, higher, especially if one considers the particularly delicate political and economic situation that Spain was undergoing.

\footnotetext{
${ }^{41}$ In particular, compulsory investment coefficients had a negative impact on equilibrium quantities in the loan market, decreasing the funds available for those economic sectors more dynamic and profitable, not included as beneficiaries of cheapest sources of funds.

${ }^{42}$ Not all the deregulation measures had the same impact on economic rents. The most important measures were those related to interest rate liberalization, in particular, those of non-remunerated deposit accounts (i.e. current and savings accounts), as well as the lifting of restrictions on branches (for both commercial and savings banks). A thorough study of the impact of the Spanish banking sector liberalization on economic rents and risk incentives is in Salas and Saurina (2002).
} 
Table 2: Deregulation and financial market changes in the Spanish banking system

1969 - Interest rates are set as a function of the Central Bank discount rate.

- Interbank rates, loan interest rates over three years and industrial banks deposit rates over to years are set freely.

1970 - Establishment of a reserve requirement for banks.

1971 - Establishment of a reserve requirement for savings banks.

- Forced investment ratios for commercial and savings banks.

1974 - Lifting of restrictions to branch opening for commercial banks.

- Loan and deposit rates over two years freely determined.

- Forced investments for savings banks are reduced.

1977 - Free determination of one-year loans and deposit interest rates.

- Forced investment ratios lowered.

- Savings banks become allowed to discount commercial paper and operate in the foreign exchange market.

1978 - Partial lifting of restrictions to foreign bank entry (restrictions on the retail segment remain).

1981 - Free determination of interest rates for most assets.

- Over 6 months time deposit interest rates as well as ESP 1 million deposits become freely determined.

- Commissions on the liability side liberalized.

- Forced investments in the form of a compulsory deposit at the Central Bank are established.

1984 - Reserve requirements increased

- A new forced investment in public debt is set

1985 -New solvency regulation: Capital requirements are set as a function of risk, in 7 buckets.

- Savings banks free to open branches in their regions of origin.

- Equalization of the investment coefficient for commercial and savings banks.

1987 - All interest rates and commissions free.

- Reduction of forced investment.

1988 - Increase in loan loss provision requirements.

1989 - Savings banks allowed to open branches nationwide.

- A calendar to phase out forced investments is announced.

1990 - Strong consolidation among savings banks.

- Substantial reduction in the reserve requirements.

1991 - Mergers among savings banks although quantitatively much less important than the previous ones.

- Mutual funds start to develop rapidly primarily as a result of changes in taxation.

1992 - Changes in capital regulations (adaptation to EU rules).

Source: Salas y Saurina (2002)

\subsection{The banking crisis and the improvement of regulation and supervision}

From 1978 to 1983, Spain suffered a large banking crisis, with the closure, merge or acquisition of 52 banks out of 116 existing at the start of the crisis, which amounted to a total of $25 \%$ of total commercial banks' assets. The crisis started with small local banks, but later reached some important banking conglomerates. The causes of the crisis were a deep economic crisis and a too 
weak regulatory framework ${ }^{43}$ in the process of financial liberalization, but primarily mismanagement, related party, and single borrower lending.

In fact, as in many other cases, the banking crisis could not withstand the poor economic conditions prevailing after a period of strong economic growth. The economy had been growing briskly during the 1960's, and even in the first half of the 1970's, with average GDP growth rates close to 7\% (see graph 22), among the highest in Europe at the time. 1975 was a recession year, with GDP growth slowing to a meager $0.5 \%$ as a consequence of the oil crisis and the difficulty to take counteracting measures in a period of transition to democracy. Both wages and inflation, which were already close to double-digits, accelerated sharply contributing a strong real exchange rate appreciation and a deterioration of the current account balance. Monetary policy needed to be tightened to curb inflation, but it also increased financial costs for the corporate sector at a time of slower growth. The first symptoms of the crisis appeared in 1977 when Banco de España realized that the liquidity problems identified in a few banking institutions were hiding more severe solvency problems. $^{44}$

G22 Inflation, growth and current account deficit in Spain

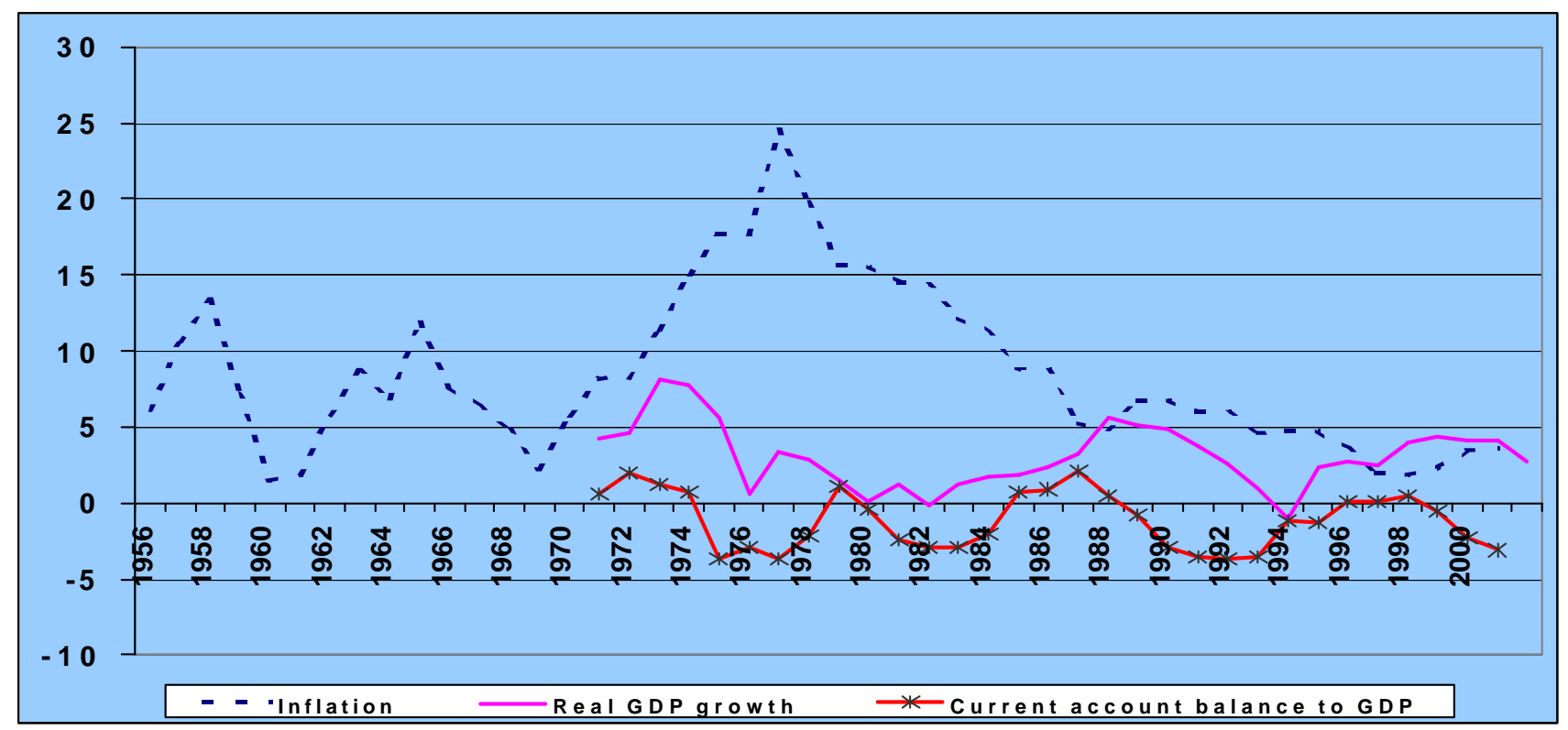

Source: Banco de España (2001)

Many of the bankrupt banks had been newly licensed during the 1960s. New bankers focused mainly on industrial banking (long term financing of non-financial firms) with important loans to the more risky real estate sector which first experienced a boom during the sixties as the country started to industrialize and later, between 1974 and 1980, benefited from the sharp decline of the stock exchange, acting as some kind of safe haven. More importantly, banks lent many of the

\footnotetext{
${ }^{43}$ A summary of the causes of the Spanish banking crisis as well as the regulatory responses can be found in Juan (1993).

${ }^{44}$ Sheng (1996).
} 
funds to the same group's non-financial firms. Lending to related parties and single borrowers inside those groups was as high as $50 \%$ in some bankrupt conglomerates ${ }^{45}$.

When the economic environment turned sour, many loans became non-performing and banks cash flows collapsed. At that point, many of the problem banks started to purchase their own shares in order to avoid a decline in market capitalization, and engaged in "creative accounting" trying to disguise their poor results in several ways ${ }^{46}$. Non-performing loans and funds invested in sustaining bank shares started to dent banks' cash flows and profitability. In order to cope with liquidity problems, some banks started to pay higher interest rates, breaching the regulatory ceilings or entered into a branch-opening process in order to attract funds. The higher costs of these strategies plus the increasingly impaired assets finally brought about bankruptcy. As banks where on the brink of bankruptcy, many managers engaged in dubious legal practices that accelerated the banks' collapse.

A few supervisory flaws made it very difficult to stop the banking crisis. First of all, banking regulations did not allow supervisors to intervene banks before bankruptcy. Moreover, there was a huge shortage of on-site supervisors, and the existing ones were more focused on assessing compliance with bank regulations than on monitoring the solvency of banks. Banco de España began to tighten supervision and information disclosure in the late 1970's, but bank regulations remained to some extent outdated until the first half of the 1980's.

The cost for the taxpayers of the banking crisis bail-out was sizeable -about 5\% of GDP -but still much smaller than many other banking crises. When the crisis started, no deposit insurance scheme (DIS) was in place. As the magnitude of the crisis was reckoned, a limited DIS jointly funded by the commercial and savings banks and by Banco de España was implemented immediately. The institution created to manage the DIS funds also received emergency restructuring powers over insolvent banks. With these powers, it could take control of a bank, writeoff losses, recapitalize banks, restructure and finally sell them to the private sector. The only exception made to this procedure occurred in 1983, when one of the country's largest banking holdings (comprising 20 banks and a number of non-financial firms) went bankrupt and was temporarily nationalized ${ }^{47}$. After some restructuring the bank holding was sold, in pieces, to other Spanish commercial banks.

From that painful experience, regulators and supervisors become aware of the importance of tight solvency regulation and supervision, and spent the following years introducing them. The cornerstone of the new approach -other than stringent solvency regulation- was a frequent on-site inspection where assets classification and proper provisioning were carefully reviewed. Banks

\footnotetext{
45 Sheng (1996) argues that none of the banks created during the financial liberalization of the 1970s survived as independent institutions, and 90\% of the banks involved in the banking crises were created between 1973 and 1978.

${ }^{46}$ These included delaying the reflection of costs, registering future income as current, not properly classifying assets (i. e. doubtful and impaired assets were kept as if they were performing) and making lower provisions than needed. See Cuervo (1988)

${ }^{47}$ It is important to realize that Spain was involved in a delicate political transitional period which added uncertainty to the economic and banking crisis.
} 
were required to comply with stricter capital requirements ${ }^{48}$. The "guarantee coefficient" (calculated as liabilities to capital) was substituted by a solvency coefficient in which different asset classes were required a different level of capital (from $0,25 \%$ to $35 \%$ ) in 1985, which was very similar in substance to that later agreed in the Basel accord of 1988. In addition, credit-risk concentration limits were applied relative to capital requirements (as it turned to be one of the main leading causes of the former banking crisis), tighter entry requirements for new banks were also introduced, together with early intervention and stronger sanctions for rule breakers. Finally, professional as well as honorability requirements to become a banker were established, and regulators were provided with the ability to intervene banks when in doubt of their solvency and liquidity.

Since the end of the 78-83 banking crisis, a few very small banks and one larger bank have gone bankrupt, although a large bank had problems which were decisively tackled by the authorities in late 1993. Mismanagement and, in some instances, fraud were the main causes of these episodes. Fortunately, as a result of the new regulatory environment, losses for taxpayers were minimized.

\subsection{The change in the bank structure: Commercial banks versus savings banks}

An important consequence of financial liberalization was the blurring of the difference between commercial and saving banks although at a somewhat late stage in the liberalization process since the deregulation of savings banks started later. While commercial banks were allowed to open branches nationwide relatively early in the liberalization process, savings banks had to wait until 1989. Saving banks also had to comply with higher forced investments. Interestingly enough, despite the longer-maintained regulatory burdens, savings banks managed to increase market share in loans as well as in deposits at the expense of banks, quite differently from what has happened in many European countries. This was particularly important after saving banks were granted the opening of branches nationwide, which led to several mergers and even some acquisitions of commercial banks by some of the largest saving banks.

Notwithstanding the deregulation, savings banks continue to be different since their legal status is close to that of a commercial non-profit organization ${ }^{49}$. They have to compete for deposits and loans in the market under similar conditions than commercial banks but profits have to be either retained or distributed in cultural and social community programs. Despite this diffuse ownership structure, savings banks achieve similar or even higher levels of profitability and efficiency than commercial banks. They hold strong, usually regional, retail franchises with dense branch networks, and recently, even national in the largest cases.

\footnotetext{
${ }^{48}$ More stringent than the Basel capital ratio since general provisions and unrealized gains are not counted as own funds.

${ }^{49}$ The governance of savings banks is shared among representatives of several stakeholders groups, public authorities (from local and regional government), the founding entity, depositors and workers. Since several stakeholders groups have voice in the administration and supervision bodies, there is a risk that each group may try to influence managers to take decisions in their own benefit. The real objective function of the savings and loans banks is thus difficult to know, although anecdotal evidence indicates that managers and workers are possibly the most powerful interest groups in the organization. Depositors' representatives are elected from a randomly selected election body, and public-sector representatives belong to different political parties.
} 
Savings banks are also important in Spain from a financial development and stability perspective due to their complementary role to that of commercial banks. Being primarily domestically-oriented, they act as a cushion for the maintenance of enough intermediation, together with small and medium-sized commercial banks in Spain, which have not embarked in outward internationalization as the two largest banks. The financial stability perspective is also relevant in view of the fact that Spanish banks outward internationalization has focused in emerging markets, especially Latin America. Since the rest of the Spanish banking system -which account for nearly two thirds of total assets - is to a greater extent sheltered from international developments, they could, in the event of difficulties in the large banks, play an important role as a "spare tire" to maintain financing levels at home.

\subsection{The process towards international and regional integration}

\section{i) $\quad$ Foreign banks in Spain}

Foreign banks were not allowed to operate in Spain until 1978, when banking franchises started to be offered but still under important restrictions. Among the most relevant, foreign banks could open only a limited number of branches nationwide, they were not allowed to buy stakes in non-financial Spanish firms and they could only fund $40 \%$ of their investments in the Spanish market while the rest had to come from abroad.

The main policy objective for maintaining these restrictions at that time was to open the Spanish banking system to foreign competition without causing large disruptions in the domestic market. Foreign banks were believed to bolster innovation and competition as well as efficiency but there was the perception that domestic banks might note be able to withstand the competition. In reality, when foreign banks started to enter the domestic market, they focused primarily on the wholesale business. The interbank market deepened as a result of new participants coming into the market. As foreign banks started to expand into retail sectors- albeit at a low pace and usually in niche markets - non-financial firms as well as customers benefited of a wider access to banking services. It is interesting to note that one of the easiest ways for foreign banks to enter the Spanish retail market was to buy restructured banks from the DIS. In this way, the DIS managed to dispose of several of the banks it had intervened over during the banking crisis.

In general, foreign banks never reached a major share in the Spanish banking system. From $8 \%$ of total assets in 1985 they reached $11,7 \%$ in 1997 and gradually decreased to the current $10 \%$ of total assets. For many of the foreign banks, learning about local credit policy and adequate risk management for the country's financial habits took time, and the amount of non-performing loans strained profit and losses accounts more than expected. Other foreign banks changed their strategies several times (focusing first only in firms, later in households, mortgages or consumer loans, etc.) attaining different degrees of success. In the end, just a few foreign banks proved to be successful in the retail business, achieved medium size, and spread all over the country. The others left the country after pursuing commercial strategies with very aggressive pricing policies to lure customers. Finally, those which focused on wholesale markets (mainly branches of foreign banks) generally obtained thin margins and low profitability in terms of return on assets. 
The response of Spanish banks to the threat of foreign competitors entering the market helps explain the difficulties that foreign banks faced to increase market share significantly. Confronted directly with foreign competition, Spanish banks improved processes, rationalized their networks and operational procedures, updated their IT systems and became more competitive in their pricing policies. Moreover, they improved the quality of their services to retail customers through an extensive ATM network, the largest in Europe today in relative terms. All these changes added to the tradition of customer relations based on confidence, mutual knowledge, proximity and understanding of customers' needs allowed incumbents to protect their market share. High branch density also contributed, at least in part, to the high customer loyalty which characterizes the Spanish banking system.

The result of all these changes was a sharp increase in efficiency among Spanish incumbents, which is shown by the sharp decline in the net interest margin in the 1990s. Net interest margins in Spain, at 3.9\% to total assets, ranked among the highest in Europe at the beginning of 1990s. Increased competition during the 1990s cut them in half, and today, at $2.2 \%$, net interest margin figures compare well with countries such as the UK or Italy, although they appear high vis-a-vis Germany or France.

Recently, some foreign banks have entered the Spanish banking system using telephone and internet premises. Theoretically, they exploit lower costs in IT services and pay higher interest rates advantage to attract customers. For the time being, these banks have generally not been profitable, especially if one considers the high cost of their liabilities and the need for a critical mass of customers. In the future, results might improve once they have a large enough customer base and cross selling takes off although, as already happened before, Spanish banks have reacted rapidly offering telephone and internet banking as an alternative channel for some of their customers. However, adverse selection may become a critical problem when they step up their lending through telephone and the internet.

\section{ii) Outward internationalization: Latin America}

One of the distinguishing features of the Spanish banking system in the last few years has been its rapid outward internationalization process mostly concentrated in Latin America. Today, slightly less than one fourth of the assets of the Spanish banking system are abroad, half of which in Latin America. The other half concentrates in developed countries, mainly western Europe, which is an important sign of regional integration, as will be tackled later. The exposure of Spanish banks to Asia, East Europe, Africa and Middle East is very low.

Although some Spanish banks already had a presence in Latin America, it is not until 1996 when their participation increases significantly, as a result of purchases of local banks, in many cases through privatization processes. The largest move forward in this strategy occurred in 2000 , when the Spanish banks increased significantly their market shares in the largest economies of the region: Mexico and Brazil, which meant a qualitative and quantitative jump in terms of their predominant role in the Latin American banking system. Today, Mexico is the country in the region where Spanish banks concentrate the largest share of their investment (see graph 23), followed at a long distance by Brazil, Chile and Argentina (less that 15\%) 
Apart from banks, Spanish banks have also bought pension fund managing firms. This tends to be a lower risk business, with more stable cash flows coming from fees, as many Latin American countries do not have public pension schemes. Another source of expansion is the insurance sector, although its market share is still relatively low.

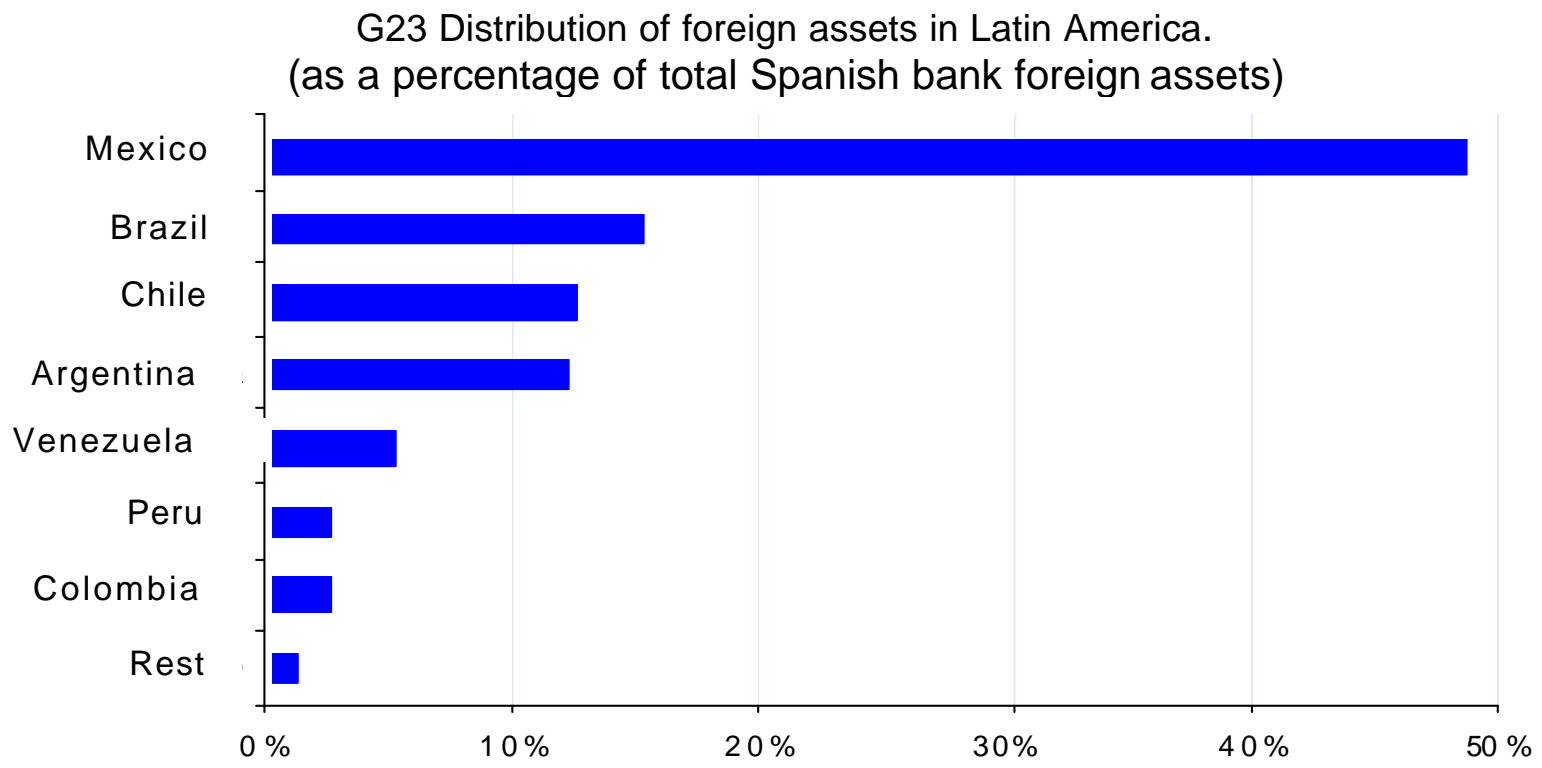

Source: Banco de España (2001)

The reasons behind the expansion in Latin America are manifold. First of all, Latin American countries offer growth opportunities because the level of banking products and services to GDP is relatively low. At the same time, Spanish banks moved into Latin America hand in hand with their main local corporate customers, who have also expanded in this region through foreign direct investment. Larger margins and potential efficiency gains from the introduction of a new technology and well-designed financial services which had been very successful in Spain, were important reasons for the Spanish banks to expand in Latin America. This is particularly the case if one considers the strong competition among Spanish banks at home and the fact that margins had been declining since the beginning of the 1990s. Risk diversification has been another reason to expand abroad, with the aim to profit from different cycles in other countries.

Last, but not least, the fact that many Latin American countries share a common language and similar idiosyncrasy helps considerably take control of a bank purchased in the region. Middle management can be sent to the acquired bank, and business policy and practices can be easily transferred.

Market capitalization of Spanish banks operating in Latin America surged, implying that income growth potential, efficiency gains and confidence in management clearly outweighed the larger risk implied in operating in the region. Recent developments in Argentina show that there may be situations in which the higher return of the Spanish outward internationalization is also coupled with higher risk. However, this higher risk has not affected the solvency of the Spanish bank groups operating in Latin America. 


\section{iii) Regional integration with the rest of the EU}

Since Spain joined the European Union in 1986, the country has taken all the necessary steps to become as integrated as possible with the rest of the European financial system. The Second Banking Directive was adopted in January 1993, which implied a common passport for other EU banks in Spain and for Spanish banks in other EU countries. This has facilitated even further the entrance of foreign banks in the Spanish market as well as the expansion of Spanish banks in European countries, where they currently hold nearly half of their assets abroad, as was previously mentioned. The strategy chosen by Spanish commercial - but also saving banks - in this regard has been closing alliances with major European banks, through cross-share holdings, mainly French, Italian, German, Portuguese and British. No mergers have yet taken place between Spanish banks and a European partner but this is also the general trend in Europe except for the Nordic countries. The fact is that the main source of profits for banks remains their retail business that is highly idiosyncratic to each country. Moreover, differences in legal and tax national schemes, in addition to other sort of obstacles to foreign bank mergers or acquisitions, contribute to complicate the creation of Pan European banks through cross-border mergers.

The situation in the wholesale market is quite different, not only in Spain, but also in most European countries. There is increased integration and widespread competition favored by the large economies of scale and scope in this business segment, which makes consolidation potentially more profitable. Some large European banks are relying more and more on investment banking as their core business. Finally, Bancassurance is another important source of cross border regional consolidation in Europe but not so in Spain.

The stronger integration of part of the infrastructure, particularly as regards the wholesale payment systems through TARGET, has clearly contributed to the heightened competition, and consolidation, of the wholesale market. Moreover, the rapid growth of Euro bond markets since the onset of the EMU has expanded the business opportunities for large European banks in terms of non-financial firms financing.

\section{Conclusions and possible lessons from the Spanish experience for Asian countries}

A brief review of the literature on some determinants of financial development highlights the importance of a deep, balanced and efficient financial structure, a well-sequenced financial liberalization, strong bank regulation and supervision and international (and regional) financial integration for the development of the financial system.

A brief comparison of the Asian and European financial systems indicates that a few of the steps taken in the two regions in the quest for financial development and stability are very similar in timing and nature. This is particularly the case for the move towards a more balanced financial structure, which basically started in the early 1990s in both regions. Other steps are similar in nature but not in timing, such as financial liberalization, which started later in Asia and suffered from more reversals, and the strengthening of the regulatory and supervisory framework, which Asian countries only undertook after their 1998 banking crises. The most striking difference between the two areas is the degree of international - and regional - financial integration, much 
lower for Asia. As regards the banking system's opening up to foreign competition, the share of foreign ownership is relatively low in both regions but the reasons are different: regulatory restrictions basically explain the trend in Asia while strong competition is the probably the main factor of the low foreign participation in most of the Europe banking systems.

From a more detailed analysis of the case of Spain, a few useful insights can be drawn for economies in the quest for financial development and stability, such as several of the Asian countries. Financial liberalization in Spain started later than in other European countries and took longer to complete partially because of an adverse macroeconomic environment, but also because of an outdated regulatory framework and the incidence of an important banking crisis, as well as some reversal in capital account liberalization. Albeit these setbacks, Spanish banks learnt how to adjust to the new environment of increased competition through the opening to foreign competition. This improved efficiency has allowed Spanish banks to follow a strategy of outward internationalization in the second half of the 1990s. Financial liberalization, among other reasons, also increased financial depth and the availability of credit in Spain and favored a better-balanced financial structure, with a larger presence of capital markets. Finally, it also translated into shrinking intermediation margins, with a clear beneficial effect on the economy as a whole.

However, the Spanish experience also highlights the importance of the sequencing of financial sector reforms when the regulatory environment is weak since moral hazard tends to increase, at least in the short run, in a more liberalized system. However, financial liberalization was not the main cause of the Spanish banking crisis but rather bank mismanagement and related-party lending. These were clearly very important explanations of the Asian crisis as well. The Spanish experience shows how important it is to improve solvency regulation and to carry out regular onsite supervision. In fact, the banking crisis had a catalytic role for the improvement of bank regulation and supervision in Spain, as has later happened in many Asian countries. In addition, an explicit - and limited - deposit insurance scheme was introduced in Spain during the banking crisis, which served well to increase the public's confidence in the banking system. Several Asian countries still have to move to a more explicit and limited system, which reduces moral hazard.

From a sound and competitive situation achieved through better supervision, but also better management in view of the fierce competition from the opening up to foreign banks, Spain embarked in an outward internationalization process in the second half of the 1990s, reaching a predominant role in Latin American financial systems. In addition, Spain has also increased its participation in several European banking sectors, particularly through cross-share holdings and strategic alliances.

Challenges remain for the future, among them, contributing to the creation of a more integrated and more efficient single market for banking services in Europe. However, with the benefit of hindsight, the Spanish experience appears today as a success story in the quest for financial development and stability. 


\section{REFERENCES}

Allen, Franklin, and Douglas Gale (2000) "Comparing Financial Systems." MIT Press.

Bagehot, Walter (1873) "Lombard Street: A Description of the Money Market." Philadelphia: Orion Editions.

Bailliu, Jeannine N. (2000) "Private Capital Flows, Financial Development, and Economic Growth in Developing Countries." Bank of Canada.

Barth, James, Gerard Caprio, and Ross Levine (2001) "Banking Systems around the Globe: Do Regulation and Ownership Affect Performance and Stability?" In Prudential Regulation and Supervision: Why It Is Important and What Are the Issues. Edited by Frederic Mishkin, National Bureau of Economic Research.

Beck, Thorsten, Asli Demirguc-Kunt, and Ross Levine (1999) "A New Database on Financial Development and Structure". World Bank.

Bekaert, Geert, Campbell R. Harvey, and Robin L. Lumsdaine (2000) "Dating the Integration of World Equity Markets." National Bureau of Economic Research, NBER Working Paper No. 6724.

Berger, Allen N. (2000) "The Integration of the Financial Services Industry: Where are the Efficiencies?" Federal Reserve System, paper No. 2000-36.

Boyd, John, Ross Levine, and Bruce Smith (2000) "The Impact of Inflation on Financial Sector Performance." Journal of Monetary Economics.

Caprio, Gerard, and Daniela Klingebiel (1999) "Episodes of Systemic and Borderline Financial Crises." World Bank.

Caprio, Gerard, and Patrick Honohan (1999) "Restoring Banking Stability: Beyond Supervised Capital Requirements." In Journal of Economic Perspectives, No. 13(4), 43-64.

Caprio, Gerard, James A. Hanson, and Patrick Honohan (2001) "The Case for Liberalization and Some Drawbacks." In Financial Liberalization. Edited by Caprio, Honohan, and Stiglitz.

Chen, Bee-Lon, Yeong-Yuh Chiang, and Ping Wang (1996) "A Schumpeterian Model of Financial Innovation and Endogenous Growth." Mimeo.

Chul Park, Yung (1993) "The role of finance in economic development in South Korea nd Taiwan" In Finance and development: issues and experience. Edited by Giovannini

Claessens, Stijn, Asli Demirguc-Kunt, and Harry Huizinga (2000) "How Does Foreign Entry Affect the Domestic Banking Market?" In The Internationalization of Financial Services: Issues and Lessons for developing Countries. Edited by Claessens and Jansen.

Crystal, Jennifer S., Dages. B. Gerard, and Goldberg, Linda S. (2001) "Does Foreign Ownership Contribute to Sounder Banks in Emerging Markets? The Latin American Experience." Federal Reserve Bank of New York

Cuervo, Alvaro (1988) "La crisis bancaria en España. 1977-1985".Ariel S.A.

Cull, Robert, Lemma W. Senbet, and Marco Sorge (2000) "Deposit Insurance and Financial Development." World Bank. 
Dale, Richard and Bruni Franco and Boissieu (2000) "Strengthening Financial Infrastructure. Deposit Insurance and Lending of Last Resort" Société Universitaire Européenne de Recherches Financières. $n^{\circ} 7$.

Davis, E. Philip (2001) "Multiple Avenues of Intermediation, Corporate Finance and Financial Stability." International Monetary Fund, Working Paper No. 115.

Demirguc-Kunt, Asli, and Enrica Detragiache (1998) "Financial Liberalization and Financial Fragility." World Bank.

Demirguc-Kunt, Asli, and Ross Levine (1999) "Bank-Based and Market-Based financial Systems: Cross-Country Comparisons." World Bank, Policy Research Working Paper No. 2143.

Demirguc-Kunt, Asli, and Kane Edward J. (2001) "Bank-Based and Market-Based financial Systems: Cross-Country Comparisons." World Bank, Policy Research Working Paper No. 2143

Demirguc-Kunt, Asli, and Kane Edward J. (2001) "Deposit insurance around the globe: where does it work?" World Bank and Boston College.Mimeo

European Central Bank (1999): "Possible effects of the EMU on the EU banking systems in the medium to long term". February, 1999.

European Central Bank (2000a): “EU banks' income structure”. April, 2000

European Central Bank (2000b): "Mergers and acquisitions involving the EU banking industryFacts and implications". December, 2000.

Fernández de Lis, Santiago, Jorge Martínez Pagés and Jesus Saurina (2001): "Credit growth, problem loans and credit risk provisioning in Spain", in: "Marrying the macro and microprudential dimensions of financial stability", BIS Papers, No. 1, March, pp. 331-353.

Fuentelsaz, Lucio and Vicente Salas (1994): "Spatial competition in retail banking: Theory and empirical evidence from Spain and other European countries". SUERF.

García Herrero, Alicia et al. (2002) "Latin american financial development in perspective" presented at the ECB Workshop on Latin America, Frankfurt 21-22 March, 2002, mimeo

Giovanni, Albertor and Mayer, Colin (1990) "European Financial Integration" Cambridge University Press

Greendwood, Jeremy (1986) "Financial Liberalization and Innovation in Seven East Asian Economies" In Financial Innovation and Monetary Policy: Asia and the West. Edited by Yoshio Suzuki and Hiroshi Yomo.

Gual, Jordi, (1999) "Third Prize. Deregulation, integration and market structure in European banking" ElB papers, Volume 4 № 2.

Hawkins, John, and Dubravko Mihaljek (2001) "The Banking Industry in the Emerging Market Economies: Competition, Consolidation and Systemic Stability - An Overview." Bank of International Settlements, BIS Papers No. 4.

IMF (2000) "Finance for Growth: Policy Choices in a Volatile World" International Monetary Fund. 
Jaffee, Dwight, and Mark Levonian (2000) "The Structure of Banking Systems In Developed and Transition Economies." Federal Reserve Bank of San Francisco.

Johnston Barry, R and, Darbar, Salim M. and Echeverria, Claudia (1997) "Sequencing Capital Account Liberalization: Lessons form the Experiences in Chile, Indonesia, Korea, and Thailand" International Monetary Fund Working Paper WP/97/157

Johnston Barry, R (1998) "Sequencing Capital Account Liberalizations and Financial Sector Reform" International Monetary Fund paper on Policy Analysis and Assessment. PPAA/98/8

Juan, Aristóbulo de (1993): Dealing with problem banks: the case of Spain (1978-1984), in Blommestein, H. J. and J. R. Lange: "Transformation of the banking system: portfolio restructuring, privatization and the payment system". OECD Publications Service, Paris.

Kaminsky, Graciela Laura, and Sergio L. Schmukler (2001) "On Booms and Crashes: Financial Liberalization and Stock Market Cycles." World Bank, mimeo.

Khan, Mohsin S., Abdelhak S. Senhadji, and Bruce D. Smith (2001) "Inflation and Financial Depth." International Monetary Fund, Working Paper No. 44.

King, Robert G., and Ross Levine (1993) "Finance and Growth: Schumpeter Might Be Right." Quarterly Journal of Economics, vol. 108(3)

Kono, Masamichi, and Ludger Schucknecht (1999) "Financial Services Trade, Capital Flows, and Financial Stability." WTO, mimeo.

Kroszner, Randall S. (1998) "On the Political Economy of Banking and Financial Regulatory Reform in Emerging Markets." Graduate School of Business, University of Chicago.

La Porta, Rafael, Florencio Lopez-de-Silanes, Andrei Shleifer, and Robert W. Vishny (1997) "Legal Determinants of External Finance." Journal of Finance, vol. 52, 1131-1150.

Levine, Ross (1991) "Stock Markets, Growth, and Tax Policy." In Journal of Finance, vol. 46, 144565.

Levine, Ross, and Sara Zervos (1998) "Stock Markets, Banks, and Economic Growth." American Economic Review, vol. 88, 537-558.

Levine, Ross, Norman Loayza, and Thorsten Beck (1999) "Financial Intermediation and Growth: Causality and Causes." Central Bank of Chile, paper No. 56.

McKinnon, Ronald (1973) "Money and Capital in Economic Development, Washington: Brookings Institution. (1991) The Order of Economic Liberalization, financial Control in the Transition to a Market Economy, Baltimore and London: The Johns Hopkins University Press. In Finance and development: issues and experience. Edited by Giovannini

Rousseau, Peter L., and Richard Sylla (2001) "Financial Systems, Economic Growth, and Globalization." Mimeo.

Salas Vicente, and Jesus Saurina (2002): "Deregulation, market power and risk behaviour in Spanish banks". Forthcoming, European Economic Review.

Schumpeter, Joseph A. (1911) "A Theory of Economic Development." Cambridge, MNA: Harvard University Press. 
Shaw, Edward. S. (1973) "Financial Deepening in Economic Development" New York: Oxford University Press. In Finance and development: issues and experience. Edited by Giovannini

Sheng, Andrew (1996) "Bank Restructuring. Lessons from the 1980s." The World Bank.

Shirai, Sayuri (2001) "Overview of Financial Market Structures in Asia. Cases of the Republic of Korea, Malaysia, Thailand and Indonesia" ADB Institute Research Paper 25

Vives, Xavier (1990) "Banking competition and European integration" In European Financial Integration. Edited by Giovannini and Mayer.

Williamson, John, and Molly Mahar (1998) "A Survey of Financial Liberalization." Princeton University, International Finance Section, Essays in International Finance No. 211.

World Bank (2000) "Deposit insurance Database" 